J. Dairy Sci. 96:7093-7109

http://dx.doi.org/10.3168/jds.2012-5663

(C) American Dairy Science Association ${ }^{\circledR}, 2013$.

\title{
Dietary starch source and protein degradability in diets containing sucrose: Effects on ruminal measures and proposed mechanism for degradable protein effects ${ }^{1}$
}

\author{
Mary Beth Hall ${ }^{2}$ \\ US Dairy Forage Research Center, US Department of Agriculture-Agricultural Research Service (USDA-ARS), Madison, WI 53706
}

\begin{abstract}
A feeding study was conducted to evaluate ruminal effects of starch source (STA) and rumen-degradable dietary protein (RDP) in diets with added sucrose. The experimental design was an incomplete Latin square with three 21 -d periods, 8 ruminally cannulated lactating cows, and a $2 \times 2$ factorial arrangement of treatments. Treatments were STA (dry ground corn or high-moisture corn) as more slowly and more rapidly fermenting starch sources, respectively, and relative amount of RDP (+RDP: added protein from soybean meal; -RDP: heat-treated expeller soybean product partially substituted for soybean meal). Diets were formulated to be isonitrogenous and similar in starch and neutral detergent fiber concentrations. Dry matter $(\mathrm{DM})$ intake was $1 \mathrm{~kg}$ greater with +RDP compared with $-\mathrm{RDP}$ diets. For ruminal digesta measures made $2 \mathrm{~h}$ postfeeding, weight of digesta DM was unaffected by treatment; total kilograms of wet digesta and kilograms of liquid tended to be greater with $+\mathrm{RDP}$ than with -RDP, and no effect was observed of STA $\times$ RDP. Digesta DM percentage was greater with $-\mathrm{RDP}$ than with +RDP. At $2 \mathrm{~h}$ postfeeding, ruminal pool sizes (mol) of lactate and total AA were larger and those of total organic acids (OA) and ammonia tended to be larger with $+\mathrm{RDP}$ than with $-\mathrm{RDP}$; no effects of STA or STA $\times$ RDP were detected. Rumen-degradable protein effects on lactate and OA pool sizes may be due to a protein-mediated increase in fermentation rate of carbohydrate. Organic acid concentrations at $2 \mathrm{~h}$ postfeeding did not show the same response pattern or significance as the pool size data; high-moisture corn tended to be greater than dry ground corn and no effect was observed for RDP or STA $\times$ RDP. Concentration and pool size for OA were more weakly correlated [coef-
\end{abstract}

Received April 26, 2012

Accepted July 24, 2013.

${ }^{1}$ Mention of any trademark or proprietary product in this paper does not constitute a guarantee or warranty of the product by the USDA or the Agricultural Research Service and does not imply its approval to the exclusion of other products that also may be suitable.

${ }^{2}$ Corresponding author: marybeth.hall@ars.usda.gov ficient of determination $\left.\left(\mathrm{R}^{2}\right)=0.66\right]$ than was the case for other ruminal analytes $\left(\mathrm{R}^{2}>0.80\right)$. Organic acid pool size and kilograms of digesta liquid were strongly correlated $\left(\mathrm{R}^{2}=0.79\right)$, whereas concentration and kilograms of liquid were much less so $\left(\mathrm{R}^{2}=0.21\right)$. The correlation of OA moles with kilograms of liquid likely relates to the homeostatic mechanism of water flux across the rumen wall to reduce the osmotic gradient with blood as intraruminal moles of solute change. This action compresses the range of ruminal OA concentrations. With kilograms of ruminal liquid differing across individual measurements, the ruminal OA concentration data are not on the equivalent basis required to be reliably useful for assessing the effect of treatments. Further evaluation of protein effects on carbohydrate fermentation and of methods that allow accurate comparison of treatments for their effect on ruminal OA production are warranted.

Key words: fermentation, protein degradability, rumen, starch

\section{INTRODUCTION}

The concept of increasing animal productivity and efficiency by synchronizing the ruminal availability of carbohydrate and protein sources has long been proposed (Johnson 1976). However, the focus for synchrony has largely been on increasing efficiency of microbial N production (Kim et al., 1999) with little commentary regarding the effect of dietary protein on ruminal carbohydrate utilization. Increases in ruminally available protein have been shown to increase organic acid concentrations irrespective of the ruminal availability of carbohydrate (Herrera-Saldana and Huber, 1989; Aldrich, et al., 1993; Carruthers and Neil, 1997; Hall et al., 2010). The effect of protein degradability on these ruminal measures has also been shown to differ, depending on the supplemental carbohydrate source (dry ground corn, citrus pulp, or sucrose + molasses; Hall et al., 2010). Ruminally degradable protein has also been shown to affect ruminal $\mathrm{pH}$, with greater amounts of $\mathrm{RDP}$ associated with lower ruminal $\mathrm{pH}$ values (Aldrich, 
et al., 1993; Hall et al., 2010). These effects of RDP would seem to contradict the general view that production of organic acids is driven primarily by ruminal availability of carbohydrate.

Protein-mediated changes in production of rumen VFA or $\mathrm{pH}$ would alter supply of nutrients to the cow and are not presently predicted in nutritional models. Insights into factors that generate such effects could allow design of dietary manipulations to increase energy derived from the diet and thus enhance animal performance and efficiency. The objective of this study was to evaluate effects of starch source, dietary protein degradability, and their interaction on ruminal variables. Cow behavior (rumination, eating, lying, standing, drinking, grooming, and sleeping), intake, and lactation performance were also measured, and the resulting data provided additional insights into factors that could affect ruminal function and the effect of treatments.

\section{MATERIALS AND METHODS}

\section{Cows, Diets, and Facilities}

The experiment was conducted at the US Dairy Forage Research Center (Prairie Du Sac, WI) from May through July 2008. Eight ruminally cannulated Holstein cows (DIM: $158 \pm 58$; parity: $1.9 \pm 1.0$; milk production: $45.4 \pm 3.4 \mathrm{~kg}$; BW: $630 \pm 46 \mathrm{~kg}$; cannulas: $10 \mathrm{~cm}$ i.d.; Bar Diamond Inc., Parma, ID) were used. Cows were housed and fed individually in a tie-stall barn, with diets offered in ad libitum amounts once daily at approximately $0700 \mathrm{~h}$. Cows were milked twice daily in a parlor at 0430 and $1530 \mathrm{~h}$. Ambient temperature and humidity recorded hourly for $48 \mathrm{~h}$ on $\mathrm{d} 17,18$, and 19 (Big Digit Hygro-Thermometer 445703; Extech Instruments Corp., Waltham, MA) averaged $18.8^{\circ} \mathrm{C}$ and $76 \%$ relative humidity from 0100 to $1200 \mathrm{~h}$ and $22.6^{\circ} \mathrm{C}$ and $65 \%$ relative humidity from 1200 through $2400 \mathrm{~h}$. Animals were maintained under protocols approved by the University of Wisconsin Institutional Animal Care and Use Committee (Madison).

The design of the study was an incomplete Latin square (Steel and Torrie, 1960) with a $2 \times 2$ factorial arrangement of treatments and 3 periods. Cows were randomly assigned to a series of 3 of the 4 dietary treatments, arranged such that in the entire study each treatment followed every other treatment including itself (Table 1). The periods were $21 \mathrm{~d}$ in length, with 14 $\mathrm{d}$ for acclimation and $7 \mathrm{~d}$ for sample collection.

The dietary treatments were designed to provide different starch source and protein degradabilities. Starch source treatments used dry ground corn (DG) and ensiled high-moisture corn (HM) to provide more slowly or more rapidly fermenting starch sources, respectively. The 2 treatments differing in dietary concentrations of RDP were achieved by supplementing with $48 \%$ soybean meal (+RDP) or partially substituting heattreated expeller soybean product (SoyPLUS; West Central Cooperative, Ralston, IA) for $48 \%$ soybean meal (-RDP). All diets were formulated to contain similar basal concentrations of forage (alfalfa silage, grass silage, and corn silage) and sucrose, to be isonitrogenous, and to contain similar concentrations of starch and NDF (Table 2). Sucrose was included to maintain greater concentrations of readily fermentable NFC and avoid the potential for reduction in ruminal $\mathrm{pH}$ sometimes associated with feeding higher concentrations of starch (Heldt et al., 1999). The concentrations of ethanol-soluble carbohydrates in these diets are within the range found in diets containing unensiled forages and feedstuffs, such as molasses or citrus pulp, that contain elevated concentrations of sugars. Characterizations of starch sources and forages are shown in Table 3. Diets were formulated to meet NRC (2001) requirements for vitamins and minerals and contained monensin.

Milk weights were recorded for all milkings during collection periods and samples collected from all milkings on d 18 through 21 of each period. Milk samples were analyzed by AgSource Milk Analysis Laboratory (Menomonie, WI) for composition by infrared analysis using a Foss FT6000 instrument (method 972.16; AOAC, 1990), and for SCC using a Foss 400 instrument (method 978.26; AOAC, 1990; Foss Electric A/S, Hillerød, Denmark). Production of $3.5 \%$ fat- and proteincorrected milk (FPCM) was calculated by the following equation (derived from Tyrrell and Reid, 1965):

$$
\begin{gathered}
3.5 \% \text { FPCM }(\mathrm{kg} / \mathrm{d})=[12.82 \times \text { fat }(\mathrm{kg} / \mathrm{d})] \\
+[7.13 \times \operatorname{protein}(\mathrm{kg} / \mathrm{d})]+[0.323 \times \text { milk }(\mathrm{kg} / \mathrm{d})] .
\end{gathered}
$$

Feed efficiency was calculated as 3.5\% FPCM divided by DMI. Efficiency of dietary $\mathrm{N}$ utilization was calcu-

Table 1. Series of dietary treatments as applied to individual cows ${ }^{1}$

\begin{tabular}{lccc}
\hline Cow & Period 1 & Period 2 & Period 3 \\
\hline 1 & $\mathrm{~A}$ & $\mathrm{C}$ & $\mathrm{B}$ \\
2 & $\mathrm{~B}$ & $\mathrm{D}$ & $\mathrm{C}$ \\
3 & $\mathrm{C}$ & $\mathrm{A}$ & $\mathrm{A}$ \\
4 & $\mathrm{D}$ & $\mathrm{B}$ & $\mathrm{A}$ \\
5 & $\mathrm{~A}$ & $\mathrm{~B}$ & $\mathrm{~B}$ \\
6 & $\mathrm{~B}$ & $\mathrm{C}$ & $\mathrm{C}$ \\
7 & $\mathrm{C}$ & $\mathrm{D}$ & $\mathrm{D}$ \\
8 & $\mathrm{D}$ & $\mathrm{A}$ & $\mathrm{D}$ \\
\hline
\end{tabular}

${ }^{1}$ Diet A: DG+RDP; $\operatorname{diet} \mathrm{B}: \mathrm{DG}-\mathrm{RDP}$; $\operatorname{diet} \mathrm{C}: \mathrm{HM}+\mathrm{RDP}$; $\operatorname{diet} \mathrm{D}$ $\mathrm{HM}-\mathrm{RDP}$, where $\mathrm{DG}=$ dry ground corn, $\mathrm{HM}=$ high-moisture corn, $+\mathrm{RDP}=$ more RDP, and $-\mathrm{RDP}=$ less RDP. 
Table 2. Diet composition ${ }^{1}$

\begin{tabular}{|c|c|c|c|c|}
\hline \multirow[b]{2}{*}{ Item } & \multicolumn{2}{|c|}{ DG } & \multicolumn{2}{|c|}{$\mathrm{HM}$} \\
\hline & $+\mathrm{RDP}$ & $-\mathrm{RDP}$ & $+\mathrm{RDP}$ & $-\mathrm{RDP}$ \\
\hline \multicolumn{5}{|l|}{ Ingredient, $\%$ of diet DM } \\
\hline Grass silage & 7.5 & 7.5 & 7.5 & 7.5 \\
\hline Corn silage & 32.5 & 32.5 & 32.5 & 32.5 \\
\hline Alfalfa silage & 15.0 & 15.0 & 15.0 & 15.0 \\
\hline Dry ground corn & 14.0 & 14.0 & 0 & 0 \\
\hline High-moisture corn & 0 & 0 & 14.0 & 14.0 \\
\hline Soyhulls & 7.5 & 6.0 & 7.4 & 6.0 \\
\hline SoyPLUS ${ }^{2}$ & 0 & 11.0 & 0 & 10.9 \\
\hline Soybean meal & 16.1 & 6.6 & 16.2 & 6.7 \\
\hline Sucrose & 6.0 & 6.0 & 6.0 & 6.0 \\
\hline Vitamin and mineral $\operatorname{mix}^{3}$ & 1.4 & 1.4 & 1.4 & 1.4 \\
\hline \multicolumn{5}{|l|}{ Composition } \\
\hline DM, \% & 61.5 & 61.6 & 59.9 & 60.0 \\
\hline Ash, \% of DM & 6.0 & 6.0 & 6.0 & 5.9 \\
\hline $\mathrm{CP}, \%$ of $\mathrm{DM}$ & 16.8 & 16.8 & 16.7 & 16.7 \\
\hline $\mathrm{NDF}, \%$ of $\mathrm{DM}$ & 29.0 & 28.9 & 28.9 & 28.9 \\
\hline Starch, \% of DM & 19.8 & 19.8 & 19.8 & 19.8 \\
\hline $\mathrm{ESC}^{4}, \%$ of DM & 9.1 & 9.2 & 8.9 & 9.0 \\
\hline $\mathrm{MOF}^{5}$ & 4.08 & 4.26 & 4.37 & 4.38 \\
\hline Mean particle size, $\mu \mathrm{m}$ & 1,753 & 1,875 & 1,910 & 1,885 \\
\hline
\end{tabular}

${ }^{1}$ Experimental treatments: $\mathrm{DG}=$ dry ground corn, $\mathrm{HM}=$ high-moisture corn, +RDP = more rumen-degradable protein, and $-\mathrm{RDP}=$ less rumen-degradable protein.

${ }^{2}$ West Central Cooperative, Ralston, IA.

${ }^{3}$ Contained (on a DM basis) $18.82 \% \mathrm{Ca}, 4.45 \% \mathrm{Mg}, 0.49 \% \mathrm{~K}, 14.51 \% \mathrm{Na}, 6.58 \% \mathrm{Cl}, 0.94 \% \mathrm{~S}, 24.4 \mathrm{mg}$ of Co/ $\mathrm{kg}, 526.4 \mathrm{mg}$ of $\mathrm{Cu} / \mathrm{kg}, 55.5 \mathrm{mg}$ of I/kg, $604.9 \mathrm{mg}$ of Fe $/ \mathrm{kg}, 2,943.8 \mathrm{mg}$ of $\mathrm{Mn} / \mathrm{kg}, 14.87 \mathrm{mg}$ of Se $/ \mathrm{kg}, 2,844.1$ $\mathrm{mg}$ of $\mathrm{Zn} / \mathrm{kg}, 291,500 \mathrm{IU}$ of vitamin $\mathrm{A} / \mathrm{kg}, 58,300 \mathrm{IU}$ of vitamin $\mathrm{D} / \mathrm{kg}, 1,390 \mathrm{IU}$ of vitamin $\mathrm{E} / \mathrm{kg}$, and $0.96 \mathrm{~g}$ of monensin $/ \mathrm{kg}$.

${ }^{4} 80 \%$ ethanol-soluble carbohydrates.

${ }^{5}$ Modulus of fineness.

lated as $(\mathrm{kg}$ of milk protein $/ 6.38) /(\mathrm{kg}$ of DMI $\times$ dietary $\mathrm{CP} \% / 6.25)$.

Cow behaviors of standing, lying, eating, ruminating, drinking, grooming, and sleeping were recorded every 5 min for $48 \mathrm{~h}$ on d 17, 18, and 19 of each period, except when the cows were away from their stalls for milking. The behavior taking place at the start of each 5 min interval was recorded and calculated as extending for the entire 5-min interval. The exception to this was drinking, which was recorded when it occurred. This approach likely overestimated the actual time spent drinking, but provided relative estimates of the time spent on this behavior. An episode for a given behavior was defined as a minimum of 2 successive recordings of the same behavior. In longer spans of time devoted to ruminating or eating, single 5-min intervals in which the cow did not continue the previous behavior, did not engage in new behavior, and subsequently recommenced the previous behavior were considered not to signal a new episode.

Table 3. Characterization of corn feeds and forages

\begin{tabular}{|c|c|c|c|c|c|}
\hline Item & $\begin{array}{l}\text { Dry ground } \\
\text { corn }\end{array}$ & $\begin{array}{l}\text { High-moisture } \\
\text { corn }\end{array}$ & $\begin{array}{l}\text { Corn } \\
\text { silage }\end{array}$ & $\begin{array}{l}\text { Alfalfa } \\
\text { silage }\end{array}$ & $\begin{array}{l}\text { Grass } \\
\text { silage }\end{array}$ \\
\hline DM, \% & 86.9 & 75.2 & 35.6 & 33.2 & 57.9 \\
\hline $\mathrm{CP}, \%$ of $\mathrm{DM}$ & 9.5 & 8.5 & 7.2 & 22.1 & 11.9 \\
\hline $\mathrm{NDF}, \%$ of $\mathrm{DM}$ & 9.1 & 8.9 & 37.8 & 35.8 & 55.1 \\
\hline Starch, $\%$ of DM & 68.6 & 68.9 & 29.9 & 1.3 & 0.4 \\
\hline $\mathrm{ESC},{ }^{1} \%$ of DM & 2.3 & 0.9 & 1.0 & 1.4 & 1.6 \\
\hline
\end{tabular}

${ }^{1} 80 \%$ ethanol-soluble carbohydrates.

${ }^{2}$ Modulus of fineness. 


\section{Sample Collection and Analysis}

Amounts of diets fed and refused were recorded daily with subsamples of TMR and orts obtained daily and composited for each diet during the 7-d collection phase of each period. Samples of silage and corn grain were obtained daily through the collection phase and composited. Concentrate feeds besides corn were sampled once during the sampling week. All samples were frozen at $-20^{\circ} \mathrm{C}$ until analysis. Subsamples of composited TMR and orts and individual feeds were dried in forced-air ovens at $55^{\circ} \mathrm{C}$; a portion of the subsamples dried at $55^{\circ} \mathrm{C}$ was subsequently dried at $105^{\circ} \mathrm{C}$ for $48 \mathrm{~h}$ to determine DM. Samples dried at $105^{\circ} \mathrm{C}$ were used for particle size determination. The individual feeds and TMR dried at $55^{\circ} \mathrm{C}$ for $24 \mathrm{~h}$ and used for compositional analysis were ground to pass the $1-\mathrm{mm}$ screen of a Wiley mill (Arthur H. Thomas Co., Philadelphia, PA). A subsample of ground material was ground to pass the 1-mm screen of an abrasion mill (Udy Corp., Fort Collins, CO). The Wiley mill-ground samples were used in analyses for CP, NDF, ash, protein degradability, CP solubility, and fermentation gas production; abrasion mill-ground samples were used for analysis of starch and ethanol-soluble carbohydrates. Daily DMI was calculated for each animal as the difference on a $105^{\circ} \mathrm{C} \mathrm{DM}$ basis between weights of feed offered and orts collected.

Neutral detergent fiber was measured using $\mathrm{Na}_{2} \mathrm{SO}_{3}$ and heat-stable $\alpha$-amylase (Multifect AA; Genencor International Inc., Rochester, NY; origin: Bacillus licheniformis; Mertens, 2002) and expressed on an ashfree basis. Starch was analyzed according to the sodium acetate buffer method described by Hall (2009). The $80 \%$ ethanol-soluble carbohydrate (used as a proxy for sugar content) was determined as described by Hall et al. (1999). Crude protein concentration as $\mathrm{N} \times 6.25$ of composited samples was determined by combustion analysis (Dumas combustion method; vario Max CN; Elementar Americas Inc., Mt. Laurel, NJ). The chemical compositions of TMR were calculated based on the proportions in the diets and chemical analyses of individual feeds, and were numerically similar to analyses of the composited TMR samples. The values for each diet from each period were averaged to give average diet compositions for the study (Table 2).

Particle size of forages and starch sources was analyzed using US standard testing sieves (Fisher Scientific Co., Pittsburgh, PA) $6.7 \mathrm{~mm}$, \#4, \#6, \#8, \#12, $\# 16, \# 20, \# 30$, and \#50 for TMR and forages and $\# 4, \# 6, \# 8, \# 12, \# 16, \# 20, \# 30$, \#50, and \#140 for corn grain. Dried feed samples were shaken through the screens for 10 min using a Ro-Tap test sieve shaker (W. S. Tyler Industrial Group, Mentor, OH). Results were used to calculate modulus of fineness (Poppi et al., 1980) and mean particle size.

Samples of corn grain and soy feeds collected in each period were analyzed to assess rates of degradation related to the intended treatment effect of the feedstuff in the diets ( $\mathrm{n}=3$ for each type of feedstuff). Samples of soybean meal and extruded soy product were analyzed with an in vitro protein degradability assay using rumen microbes (Colombini et al., 2011) to evaluate relative rates and amounts of protein degradation. The sum of ammonia-N and AA-N released as a proportion of sample $\mathrm{N}$ determined on samples providing $2 \mathrm{mg}$ of $\mathrm{N}$ are presented. Rates and volumes of gas production from fermentation of DG and HM by mixed ruminal microbes (Pell and Schofield, 1993) was evaluated using a 2-pool model (Schofield et al., 1994) and were used as estimates of rates and relative amounts of $\mathrm{OM}$ degradation. Gas production analyses were performed by RFS Technologies (Ottawa, ON, Canada). Additionally, protein solubility of corn samples was analyzed according to a modified method of Licitra et al. (1996) in which sodium azide was omitted and incubations were conducted for $1 \mathrm{~h}$ at $40^{\circ} \mathrm{C}$.

\section{Ruminal Fluid Sampling and Analysis}

Ruminal fluid samples were collected via ruminal cannulas on d 20 of each period. Starting immediately before feeding and continuing hourly for the next $5 \mathrm{~h}$, ruminal fluid (total $\sim 500 \mathrm{~mL}$ ) was collected from the craniad, ventral, and caudal areas of the rumen. Samples were immediately capped, inverted to mix, and $\mathrm{pH}$ measured with an electronic $\mathrm{pH}$ meter (315i; WTW Wissenschaftlich-Technische Werkstätten GmbH, Weilheim, Germany). Samples were filtered through 4 layers of cheesecloth, poured into $20-\mathrm{mL}$ scintillation vials, and immediately frozen at $-20^{\circ} \mathrm{C}$ until analysis. For organic acid analysis, rumen fluid samples were thawed at room temperature (approximately $23^{\circ} \mathrm{C}$ ) and centrifuged at $12,000 \times g$ for $10 \mathrm{~min}$. Organic acid concentrations in supernatant were analyzed by HPLC (Weimer et al., 1991). Total organic acids was calculated as the sum of the millimolar values for acetate, propionate, butyrate, valerate, and lactate; total $\mathrm{C}$ in these organic acids was calculated by multiplying the millimolar concentrations of organic acids by $2,3,4,5$, and 3 , respectively. Branched-chain VFA (BCVFA) were the sum of isovalerate, isobutyrate, and 2-methyl butyrate. The BCVFA were derived from ruminal degradation of AA (El-Shazly, 1952) and were not included in the molar percentage evaluation with other organic acids, which are derived predominantly from fermentation of carbohydrate. Rumen fluid samples were analyzed for AA (as leucine equivalents) and ammonia concentrations using 
flow injection analysis (Lachat QuikChem 8000 FIA; Lachat Instruments, Milwaukee, WI; Broderick et al., 2004). Ruminal pool sizes in moles of ammonia, total $\mathrm{AA}$, total organic acids, $\mathrm{C}$ in organic acids, BCVFA, and lactate were calculated for each cow in each period. The concentrations of these variables determined at 2 $\mathrm{h}$ postfeeding was multiplied by the weight of liquid digesta determined at $2 \mathrm{~h}$ postfeeding. It was assumed that $1 \mathrm{~kg}$ of digesta liquid equaled $1 \mathrm{~L}$.

\section{Ruminal Digesta Measurements}

Rumen emptying was performed $2 \mathrm{~h}$ before and $2 \mathrm{~h}$ after feeding on d 16 and 21 of each period. On each sampling day, 4 cows were sampled $2 \mathrm{~h}$ before feeding and 4 cows were sampled $2 \mathrm{~h}$ postfeeding, with all treatments represented at each sampling; each cow had pre- and postfeeding digesta data in a period with the measurements made on separate days. Rumen contents were manually removed via the rumen cannula and placed into clean, tared 132-L plastic trash cans and 18.9-L buckets. Every 10th handful of digesta was put in the smaller bucket to provide a $10 \%$ subsample. Digesta weights were recorded, and digesta in the trash can replaced into the cow from which it came. Subsamples were mixed thoroughly by hand and three 1,000- to 1,200 -g subsamples per cow were transferred to aluminum pans to be dried at $46^{\circ} \mathrm{C}$ in a forced-air oven. After $1 \mathrm{~d}$, samples were mixed and crusts broken to facilitate drying. Samples were allowed to dry for approximately $3 \mathrm{~d}$, until there was no further loss of weight. Dry weights were recorded and used to calculate digesta DM weight, loss on drying (liquid weight), and DM percentage.

\section{Statistical Analysis}

Variables used in the statistical analyses were $\mathrm{Y}=$ the dependent variable, $\mu=$ overall mean, $\mathrm{C}_{\mathrm{i}}=\operatorname{cow}(\mathrm{i}=1$ $\ldots 8), \mathrm{P}_{\mathrm{j}}=$ period $(\mathrm{j}=1,2$, or 3$), \mathrm{S}_{\mathrm{k}}=$ starch source $(\mathrm{k}=\mathrm{DG}$ or $\mathrm{HM}), \mathrm{R}_{\mathrm{l}}=$ ruminally degradable protein $(\mathrm{l}$ $=+\mathrm{RDP}$ or $-\mathrm{RDP}), \mathrm{H}_{\mathrm{m}}=$ sampling hour for ruminal measures $(\mathrm{m}=0 \ldots 5), \mathrm{D}_{\mathrm{n}}=$ sampling day for digesta measures $(\mathrm{n}=1$ or 2 ), and $\varepsilon=$ residual error. In the statistical models, interaction terms are represented by combinations of the letters used to represent variables. Terms including cow were treated as random variables.

Non-time-course data such as milk production, milk composition, DMI, feed efficiency, ruminal digesta data, behavior measurements, average and maximum ruminal lactate concentrations, and 2-h postfeeding concentrations and pool sizes were analyzed according to the model $\mathrm{Y}_{\mathrm{ijkl}}=\mu+\mathrm{C}_{\mathrm{i}}+\mathrm{P}_{\mathrm{j}}+\mathrm{S}_{\mathrm{k}}+\mathrm{R}_{\mathrm{l}}+\mathrm{S}_{\mathrm{k}} \mathrm{R}_{\mathrm{l}}+$
$\mathrm{P}_{\mathrm{j}} \mathrm{S}_{\mathrm{k}}+\mathrm{P}_{\mathrm{j}} \mathrm{R}_{\mathrm{l}}+\mathrm{P}_{\mathrm{j}} \mathrm{S}_{\mathrm{k}} \mathrm{R}_{\mathrm{l}}+\varepsilon_{\mathrm{ijk} \mathrm{k}}$. Models for ruminal digesta analyses included a term for day within period when digesta mass measurements were made. Lactate data were subject to square root transformation for analysis. In contrast with the recommendation of Murphy (1982), ruminal $\mathrm{pH}$ data did not require transformation for statistical analysis. The 2-h postfeeding concentration and pool size data for each analyte and rumen liquid volume were also subject to simple linear regression analyses to evaluate the relationships between pairs of these variables; correlation coefficients for these variables and DMI were also calculated. Rates and amounts of protein degradation of soybean meal and expeller soy product, and rates and volumes of fermentation gas production and protein solubility of DG and HM were evaluated with a statistical model that included terms for experimental period in which the samples were taken and feed ingredient identity.

Ruminal time course data from the 6 hourly samplings were analyzed as repeated measures in time with the model $\mathrm{Y}_{\mathrm{ijklm}}=\mu+\mathrm{C}_{\mathrm{i}}\left(\mathrm{P}_{\mathrm{j}} \mathrm{S}_{\mathrm{k}} \mathrm{R}_{\mathrm{l}}\right)+\mathrm{P}_{\mathrm{j}}+\mathrm{S}_{\mathrm{k}}+$ $\mathrm{R}_{1}+\mathrm{S}_{\mathrm{k}} \mathrm{R}_{1}+\mathrm{P}_{\mathrm{j}} \mathrm{S}_{\mathrm{k}}+\mathrm{P}_{\mathrm{j}} \mathrm{R}_{1}+\mathrm{P}_{\mathrm{j}} \mathrm{S}_{\mathrm{k}} \mathrm{R}_{\mathrm{l}}+\mathrm{H}_{\mathrm{m}}+\mathrm{P}_{\mathrm{j}} \mathrm{H}_{\mathrm{m}}+$ $\mathrm{S}_{\mathrm{k}} \mathrm{H}_{\mathrm{m}}+\mathrm{R}_{\mathrm{l}} \mathrm{H}_{\mathrm{m}}+\mathrm{S}_{\mathrm{k}} \mathrm{R}_{\mathrm{l}} \mathrm{H}_{\mathrm{m}}+\varepsilon_{\mathrm{ijk} k \mathrm{~m}}$. Cow nested within period and treatment was used, as it is the preferred way to designate specific experimental units to which repeated measures are related. Covariance structures were selected on the basis of which gave the smallest corrected Akaike information criterion value. The covariance structures chosen were autoregressive for concentrations of total organic acids and $\mathrm{C}$ in organic acids, heterogeneous autoregressive for propionate molar percentage, ante-dependence for butyrate molar percentage and concentrations of ammonia and total AA, compound symmetry for $\mathrm{pH}$ and valerate molar percentage, and heterogeneous compound symmetry for BCVFA concentration and acetate molar percentage. Least squares means for hourly data points for all time course analyses are in Supplemental Table S1 (available online at http://dx.doi.org/10.3168/jds.2012-5663).

Models were reduced when the significance of a term was $P>0.25$, with interaction terms removed before removal of terms included in an interaction. Terms for cow, period, starch source, RDP, and starch source $\times$ $\mathrm{RDP}$, and time in repeated-measures analyses were always retained. Results are reported as least squares means. The least squares means of square root transformed data were squared to back-transform them, whereas the standard errors of the difference are the transformed values, as no satisfactory approach was found to back-transform them to the same basis as the means. Significance was declared at $P<0.05$, and tendency at $0.05 \leq P<0.15$. Analyses were performed with PROC MIXED of SAS (SAS Institute, 2010). 


\section{RESULTS AND DISCUSSION}

Degradability differences were detected between the types of corn and soy products used to apply the experimental treatments. The proportion of feed $\mathrm{N}$ released as ammonia- $\mathrm{N}$ and $\mathrm{AA}-\mathrm{N}$ by ruminal microbes in vitro was greater for soybean meal $(19.2 \%)$ than for extruded soy product $(12.2 \% ; P=0.02)$. Rates of protein degradation for these soy products also differed (21.4 and $14.4 \% / \mathrm{h}$, respectively; $P=0.03)$. The greater amount of released protein degradation products and greater degradation rate suggest that the soybean meal would provide a greater amount of RDP than the extruded soy product.

Comparison of starch sources showed that rates of gas production for the rapidly fermenting pool tended to be greater for HM $(24.8 \% / \mathrm{h})$ than for DG $(16.0 \% / \mathrm{h}$; $P=0.11)$; rates for the slow pools did not differ $(3.7$ and $3.1 \%$ for HM and DG, respectively; $P=0.65$ ). No differences were detected between DG and HM in the volumes of gas produced from the rapidly fermenting pool (25.3 and $24.5 \mathrm{~mL} ; P=0.37$ ) or slowly fermenting pool (41.8 and $35.4 \mathrm{~mL} ; P=0.43$ ). The tendency for a greater rate for the fast pool with HM suggests that the corn types would differ in rate of ruminal fermentation. Protein solubility of the corn samples tended to be greater for the HM than for DG $(P=0.05$; Table $3)$. Solubility of protein in a mineral buffer has been positively correlated with ruminal in situ protein disappearance for concentrate feeds (Crawford et al., 1978). It has been suggested that protein solubility could be a useful indicator of protein degradability when applied to samples within a class of feedstuffs (Stern and Satter, 1984). Accordingly, in addition to differences in starch degradation rates, starch sources may also have differed in the amount of degradable protein they contributed to the diets.

\section{Intake and Lactation Performance}

Cows given + RDP diets consumed $1 \mathrm{~kg}$ more DM than cows given $-\mathrm{RDP}$ diets $(P=0.03$; Table 4$)$. This result is similar to the numerically greater intakes seen with feeding more degradable protein in other studies (Herrera-Saldana and Huber, 1989; Aldrich et al., 1993). Milk production tended to be greater with DG than with HM $(P=0.13)$ and, despite the lower DMI, milk production tended to be greater for cows with RDP than with + RDP $(P=0.08)$. In contrast to these results, Herrera-Saldana and Huber (1989) reported an increase in milk production when more RDP was supplemented together with a rapidly fermenting starch source, although they noted a lack of response to protein degradability treatments with a more slowly degrad- able starch source. A tendency was observed for greater production of lactose with $-\mathrm{RDP}$ than with $+\mathrm{RDP}(P$ $=0.11$ ), and for greater SNF production with DG than with HM $(P=0.12)$. Production of $3.5 \% \mathrm{FPCM}$ as well as measures of SCC, MUN, and N utilization efficiency did not differ among treatments $(P>0.21)$. With lower intakes and similar 3.5\% FPCM, the efficiency of $3.5 \%$ FPCM production tended to be greater for - RDP than for $+\operatorname{RDP}(P=0.10)$. No significant interactions of starch source and protein degradability were detected.

\section{Behavior}

Most behaviors were affected by dietary treatment. Cows receiving DG tended to spend more time eating $(P=0.14)$ but tended to have fewer episodes $(P$ $=0.13$ ) than those given HM (Table 5). Although no differences existed among treatments in the time spent ruminating $(P>0.19)$, more episodes of rumination were observed with HM than with DG $(P=0.02)$. The only detected interaction of treatments was for rumination episodes, which tended to increase for DG-fed cows when given - RDP compared with +RDP, but HM-fed cows showed the reverse pattern, with + RDP tending to elicit more episodes than $-\mathrm{RDP}(P=0.11)$. Other researchers have reported a tendency for more bouts of eating for dairy cows fed diets containing HM compared with DG, but with no effect on rumination or time spent eating (Oba and Allen, 2003a). The amount of time animals spent standing or lying in the present study tended to be influenced by starch source, with cows receiving HM spending more time standing and less time lying than animals receiving DG $(P=0.06)$. Cows spent more time sleeping if given DG than HM diets $(P=0.04)$.

Protein degradability affected the number of episodes of eating, with cows receiving $+\mathrm{RDP}$ having a greater number than those on $-\operatorname{RDP}(P=0.03$; Table 5$)$. The greater number of episodes for $+\mathrm{RDP}$ may relate to the increased DMI on that treatment compared with $-\operatorname{RDP}(P=0.03)$. Dietary protein degradability in an interaction with cooling regimen had been shown to influence time spent eating or the number of meals consumed per day by lactating dairy cows (Taylor et al., 1991), but the directions of responses varied with overall diet composition. Cows provided with + RDP in the present study tended to spend more time drinking than animals given $-\mathrm{RDP}(P=0.13)$. Intake of water is correlated to DMI and milk production (Dado and Allen, 1994), as well as to digestible N (Paquay et al., 1970). The associations of DMI and digestible N with water intake would apply to the present study if time spent drinking correlated with the quantity of liquid consumed; however, water intakes were not measured. 
Table 4. Feed intake, milk and component production, and feed efficiency

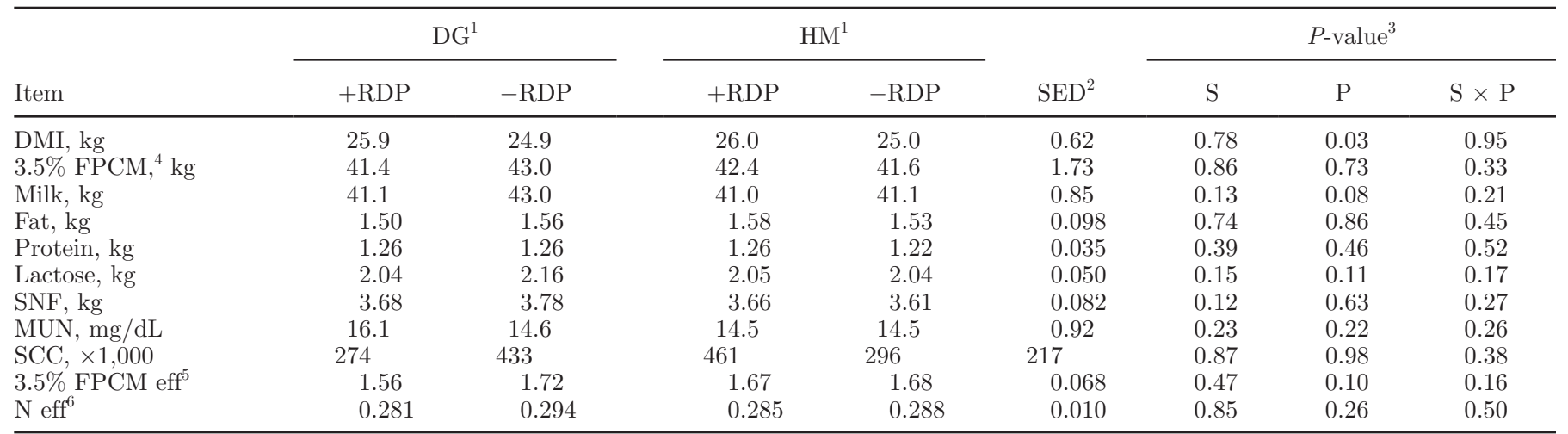

${ }^{1}$ Experimental treatments: $\mathrm{DG}=$ dry ground corn, $\mathrm{HM}=$ high-moisture corn, $+\mathrm{RDP}=$ more RDP, and $-\mathrm{RDP}=$ less $\mathrm{RDP}$.

${ }^{2}$ Standard error of the difference.

${ }^{3}$ Effects: $\mathrm{S}=$ starch source, $\mathrm{P}=\mathrm{RDP}$ treatment, and $\mathrm{S} \times \mathrm{P}=$ interaction.

${ }^{4} \mathrm{FPCM}=$ fat- and protein-corrected milk.

${ }^{5}$ Efficiency of production of $3.5 \% \mathrm{FPCM}=\mathrm{kg}$ of $3.5 \% \mathrm{FPCM} / \mathrm{kg}$ of DMI.

${ }^{6}$ Efficiency of $\mathrm{N}$ utilization $=(\mathrm{kg}$ of milk protein $/ 6.38) /(\mathrm{kg}$ of DMI $\times$ dietary $\mathrm{CP} \% / 6.25$.

The amount of time cows spent grooming themselves or neighbors tended to be greater for - RDP than for $+\mathrm{RDP}(P=0.11)$. The number of episodes per day of cows lying or standing was unaffected by RDP treatment $(P>0.35)$.

\section{Ruminal Digesta Measures}

Both starch source and RDP treatments affected ruminal digesta measures. Protein treatments consistently had the greatest effect pre- and postfeeding, whereas starch source only affected prefeeding values; starch source $\times$ RDP interactions were not significant (Table 6). Compared with cows offered -RDP diets, those offered $+\mathrm{RDP}$ diets had the greatest total $(P<$
$0.01)$ and liquid $(P<0.01)$ digesta weights prefeeding, and tended to have greater prefeeding DM weights $(P=0.12)$. Postfeeding total $(P=0.07)$ and liquid $(P=0.06)$ digesta weights also tended to be greater with +RDP than with - RDP. In this study, postfeeding weights of ruminal liquid ranged from 55 to $99 \mathrm{~kg}$. Digesta changes related to RDP supplementation have been observed in beef cows (Köster et al., 1996), where ruminal supplementation of casein increased ruminal liquid content and tended to decrease ruminal DM content. In the current study, DM percentage of digesta was lower with $+\mathrm{RDP}$ compared with $-\mathrm{RDP}$ postfeeding $(P=0.03)$, and tended to be lower prefeeding $(P$ $=0.06)$. Calculated from the means reported by Köster et al. (1996), ruminal digesta DM percentage decreased

Table 5. Daily cow behavior

\begin{tabular}{|c|c|c|c|c|c|c|c|c|}
\hline Item & \multicolumn{2}{|c|}{$\mathrm{DG}^{1}$} & \multicolumn{2}{|c|}{$\mathrm{HM}^{1}$} & $\mathrm{SED}^{2}$ & \multicolumn{3}{|c|}{$P$-value ${ }^{3}$} \\
\hline Eating & 266 & 259 & 252 & 241 & 12.3 & 0.14 & 0.36 & 0.82 \\
\hline Ruminating & 553 & 547 & 555 & 526 & 20.7 & 0.57 & 0.20 & 0.50 \\
\hline Lying & 881 & 857 & 691 & 799 & 84.2 & 0.07 & 0.49 & 0.30 \\
\hline Standing & 507 & 527 & 700 & 590 & 83.7 & 0.06 & 0.45 & 0.30 \\
\hline Sleeping & 106 & 96.9 & 77.4 & 91.8 & 8.6 & 0.04 & 0.63 & 0.15 \\
\hline \multicolumn{9}{|c|}{ Episodes, no./24 h } \\
\hline Eating & 9.6 & 8.9 & 10.2 & 9.3 & 0.36 & 0.13 & 0.03 & 0.64 \\
\hline Ruminating & 13.6 & 14.2 & 15.3 & 14.6 & 0.48 & 0.02 & 0.84 & 0.11 \\
\hline Standing & 11.9 & 12.8 & 11.6 & 10.9 & 1.5 & 0.36 & 0.92 & 0.53 \\
\hline
\end{tabular}

${ }^{1}$ Experimental treatments: $\mathrm{DG}=$ dry ground corn, $\mathrm{HM}=$ high-moisture corn, $+\mathrm{RDP}=$ more RDP, and $-\mathrm{RDP}=$ less RDP.

${ }^{2}$ Standard error of the difference.

${ }^{3}$ Effects: $\mathrm{S}=$ starch source, $\mathrm{P}=\mathrm{RDP}$ treatment, and $\mathrm{S} \times \mathrm{P}=$ interaction. 
Table 6. Ruminal digesta measurements

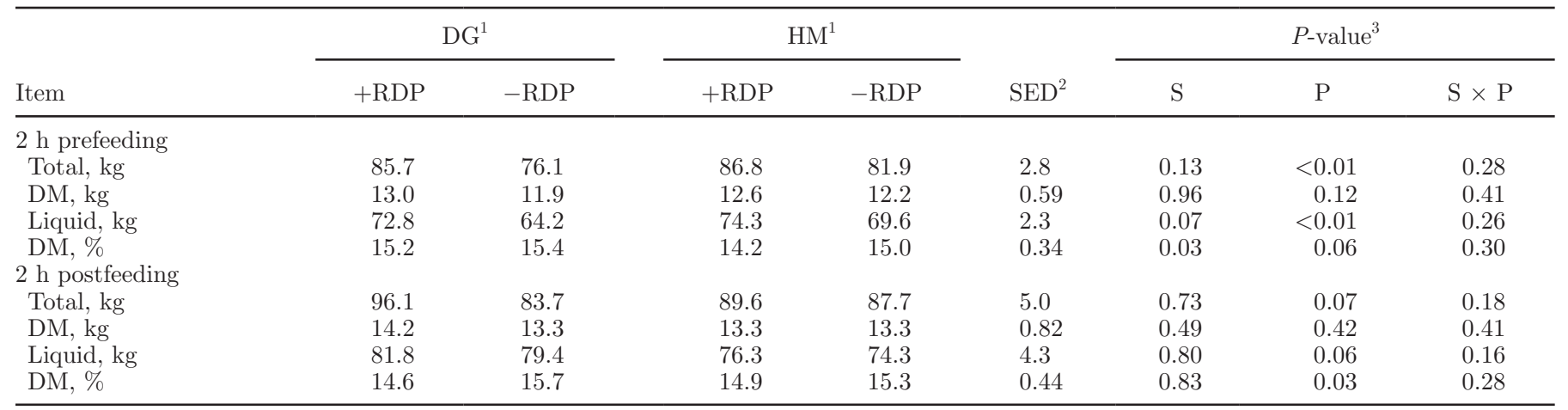

${ }^{1}$ Experimental treatments: $\mathrm{DG}=$ dry ground corn, $\mathrm{HM}=$ high-moisture corn, $+\mathrm{RDP}=$ more $\mathrm{RDP}$, and $-\mathrm{RDP}=$ less $\mathrm{RDP}$.

${ }^{2}$ Standard error of the difference.

${ }^{3}$ Effects: $\mathrm{S}=$ starch source, $\mathrm{P}=\mathrm{RDP}$ treatment, and $\mathrm{S} \times \mathrm{P}=$ interaction.

numerically with increasing ruminal casein supplementation (mean $\pm \mathrm{SD}$ were $13.2 \pm 0.11 \%$ for 0 to 360 $\mathrm{g}$ of casein/d and $10.3 \pm 0.32 \%$ for 540 or $720 \mathrm{~g}$ of casein/d). These results suggest that digesta DM percentage may decrease with increasing supplementation of degradable protein. However, effects of total versus degradable protein supplementation in the Köster et al. (1996) study cannot be separated because both were increased simultaneously.

The greater total and liquid digesta weights, and prefeeding digesta DM weights correspond to the $1-\mathrm{kg}$ greater DMI with $+\mathrm{RDP}$ than with $-\mathrm{RDP}(P=0.03)$ and a tendency for cows on $+\mathrm{RDP}$ to spend more time drinking (Table 5). Intake of water is estimated to increase by $2.38 \mathrm{~kg} / \mathrm{kg}$ of DMI (Murphy, 1992), suggesting an increase of $2.4 \mathrm{~kg}$ of water for cows given +RDP over - RDP, respectively. However, a strict relationship of water intake to DMI, does not explain the change in the ruminal ratio of water to DM represented by digesta DM percentage in the present study. In addition to the effects of DMI, a positive correlation of water intake with digestible $\mathrm{N}$ has been reported (Paquay et al., 1970). It is possible that changes in the ratio of water and DM consumed as affected by the combined influence of DMI and protein digestibility could alter ruminal digesta characteristics.

Starch source only affected prefeeding digesta measures. Digesta DM percentage was lower with HM than with DG $(P=0.03)$ and tendencies existed for reduction in total $(P=0.13)$ and liquid $(P=0.07)$ digesta weights with DG compared with HM (Table 6). Prefeeding digesta DM mass was unaffected by starch source $(P=0.96)$. No differences related to starch source were detected postfeeding (all $P>0.48$ ). The starch source-related prefeeding results for total and liquid digesta mass and DM percentage agree with the numeric pattern of findings of Oba and Allen (2003b) for cows given diets containing approximately $20 \%$ of diet DM as starch. In that study, responses to supplementation with HM or DG did not differ, but respective values were 82.1 and $78.7 \mathrm{~kg}$ for total digesta, 72.6 and $69.4 \mathrm{~kg}$ for calculated digesta liquid, and 11.6 and $11.8 \%$ for digesta DM percentage.

\section{Ruminal Fermentation Products and $\mathrm{pH}$}

Pool Sizes at 2 h Postfeeding. Ruminal fermentation product pool sizes are a function of amounts (mol) of products produced, microbial use, product absorption, and liquid passage from the rumen. Ruminal amounts of non-BCVFA organic acids are considered to be driven primarily by carbohydrate because fermented carbohydrate is the major source of these acids. However, at $2 \mathrm{~h}$ postfeeding, only RDP affected the ruminal pool size of lactate $(P<0.01)$ and tended to affect pool sizes of organic acids $(P=0.06)$ and $\mathrm{C}$ in organic acids $(P=0.05$; Table 7$)$, with $+\mathrm{RDP}$ greater than with - RDP. That total AA pool size $(P<0.01)$ was greater and ammonia tended to be greater $(P=0.08)$ with increased dietary RDP is not surprising, given that more RDP would be available for ruminal degradation, particularly with the increased DMI of + RDP cows. The AA would be derived from degradation of diet and microbes, and ruminal ammonia would be derived from those sources as well as from urea that is recycled to the rumen. However, the 14, 15, and 3,604\% increases in moles of organic acids, $\mathrm{C}$ in organic acids, and millimoles of lactate, respectively, noted with $+\mathrm{RDP}$ compared with $-\mathrm{RDP}$ are not readily explained by the $4 \%$ increase in DMI of cows consuming +RDP. No treatment differences were detected for ruminal $\mathrm{pH}$. No significant treatment interactions were detected.

Increased ruminal lactate production has been reported to be dependent on a high glycolytic flux 
Table 7. Ruminal measures of $\mathrm{pH}$, organic acids, and protein breakdown products at $2 \mathrm{~h}$ postfeeding (LSM)

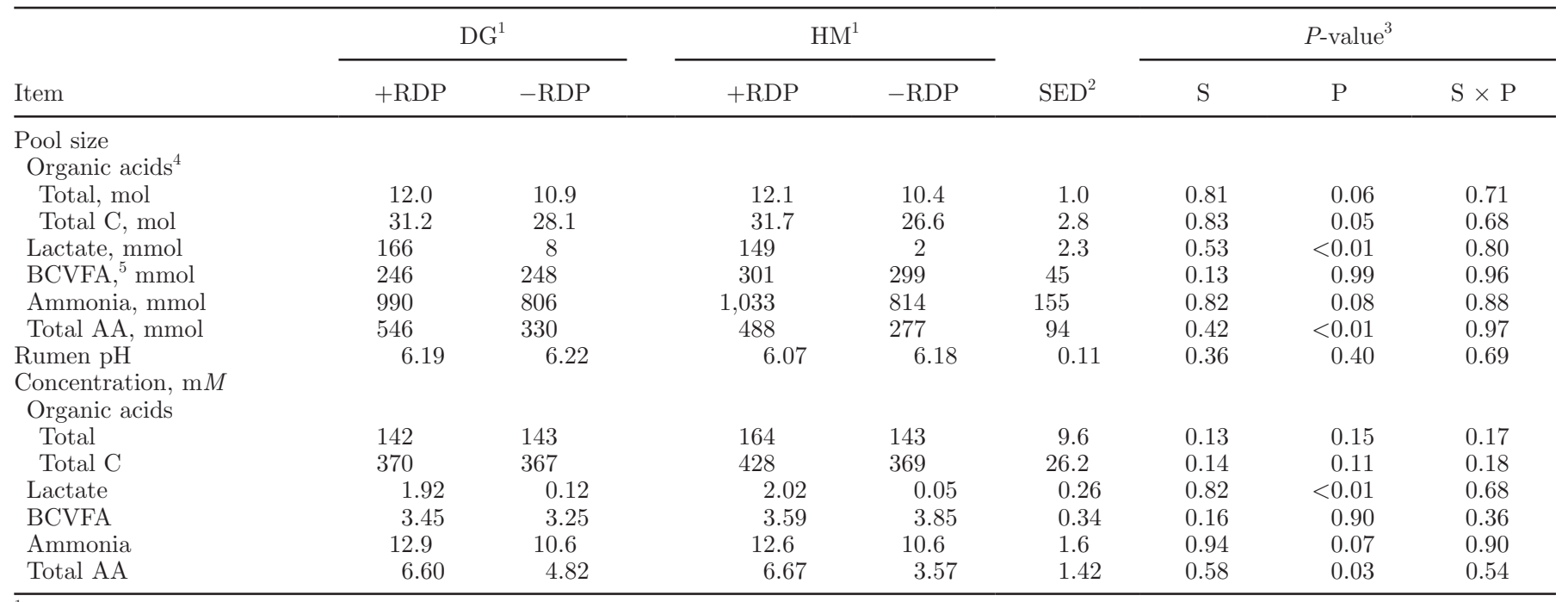

${ }^{1}$ Experimental treatments: $\mathrm{DG}=$ dry ground corn, $\mathrm{HM}=$ high-moisture corn, $+\mathrm{RDP}=$ more RDP, and $-\mathrm{RDP}=$ less $\mathrm{RDP}$.

${ }^{2}$ Standard error of the difference. Values for lactate are square root-transformed results.

${ }^{3}$ Effects: $\mathrm{S}=$ starch source, $\mathrm{P}=\mathrm{RDP}$ treatment, and $\mathrm{S} \times \mathrm{P}=$ interaction.

${ }^{4}$ Total organic acids $=$ the sum of acetate, propionate, butyrate, valerate, and lactate. Total organic acid $\mathrm{C}=$ total carbon in the summed organic acids.

${ }^{5} \mathrm{BCVFA}=$ branched-chain VFA.

(greater amounts of hexose fermented per unit time per microorganism) and ruminal $\mathrm{pH}$ (Counotte and Prins, 1981), as well as soluble protein content of the diet (Malestein et al., 1984). In the present study, the indirect indication that glycolytic flux was increased with + RDP was the tendency for a greater pool size of organic acids at $2 \mathrm{~h}$ postfeeding $(P=0.06)$.

In contrast, BCVFA pool sizes were unaffected by RDP treatment $(P=0.99)$, but tended to be greater with HM than with DG $(P>0.13)$. Degradability of the starch sources may have affected BCVFA pool sizes via increased protein degradation associated with certain starch-utilizing microbes. Although microbial populations were not measured in this study, the starch-fermenting bacteria Prevotella bryantii and Streptococcus bovis have both been shown to have proteolytic activity (Griswold et al., 1999; Boone et al., 2010), and their population sizes are known to increase when diets fed to beef cattle were switched from hay to rapidly fermented grain (Tajima et al., 2001; Fernando et al., 2010), although following adaptation, these populations have been reported to decrease to those before grain feeding or below (Tajima et al., 2001). It is possible that elevated BCVFA pool size with HM could have been due in part to increases in populations of these and other proteolytic species that grew on the rapidly available starch.

Concentrations at $2 h$ Postfeeding. Ruminal concentration data for the 2-h sampling time for total organic acids and organic acid $\mathrm{C}$ differed from the pool size data in the significance of treatments (Table 7). Starch source tended to affect concentrations of organic acids with HM more than DG (total organic acids: $P=$ 0.13 ; $\mathrm{C}$ in organic acids: $P=0.14)$. The effects of RDP and starch source on organic acid pool size showed respective differences of 13 and $2 \%$ between treatments, whereas concentrations showed differences of 7 and $8 \%$, respectively. Ruminal concentrations were greater for total AA with $+\mathrm{RDP}$ than with $-\mathrm{RDP}(P=0.03)$; ammonia $(P=0.07)$ and $\mathrm{C}$ in organic acids tended to follow the same pattern $(P=0.11)$.

The $P$-values and patterns of response were more similar between concentrations and pool sizes for ammonia, total AA, BCVFA, and lactate, but were less similar for total organic acid values. A possible basis for these differences may be discerned from the relationships among ruminal concentrations, pool sizes, and ruminal liquid volume (Table 8). Pool size in moles is calculated as the concentration multiplied by digesta liquid volume; however, pool size is not necessarily highly correlated with liquid volume. For analytes in which concentration and pool size showed approximately the same degree of correlation (moderate/strong or weak/weak) with liquid volume, the relationship between concentration and pool size was strong $\left(\mathrm{R}^{2}>0.80\right.$; Table 8$)$. However, in the case of organic acids, pool size was well correlated with liquid volume $\left(\mathrm{R}^{2}=0.79\right)$, but concentration was not $\left(\mathrm{R}^{2}=0.21\right)$; pool size and concentration were not 
HALL

Table 8. Results of simple regression analyses among ruminal concentration, pool size, and liquid volume determined $2 \mathrm{~h}$ postfeeding

\begin{tabular}{|c|c|c|c|c|c|c|c|}
\hline Analyte $^{1}$ & $\begin{array}{l}\text { Dependent } \\
\text { variable }\end{array}$ & $\begin{array}{l}\text { Independent } \\
\text { variable }^{2}\end{array}$ & Coefficient & Intercept & $\mathrm{R}^{2}$ & $\mathrm{RMSE}^{3}$ & $\mathrm{CV}, \%$ \\
\hline \multirow[t]{2}{*}{ Total OA } & $\mathrm{m} M$ & mol & 5.68 & 83.0 & 0.66 & 11.1 & 7.6 \\
\hline & $\mathrm{m} M$ & Liquid L & 0.711 & 92.7 & 0.21 & 16.9 & 11.5 \\
\hline \multirow[t]{3}{*}{$\mathrm{C}$ in $\mathrm{OA}$} & $\mathrm{m} M$ & mol & 6.07 & 203.0 & 0.68 & 30.0 & 7.93 \\
\hline & $\mathrm{m} M$ & Liquid L & 2.00 & 227.4 & 0.20 & 47.6 & 12.6 \\
\hline & mol & Liquid L & 0.524 & -10.8 & 0.76 & 3.56 & 12.3 \\
\hline \multirow[t]{3}{*}{ Ammonia } & $\mathrm{m} M$ & mmol & 0.010 & 2.88 & 0.92 & 1.11 & 9.5 \\
\hline & $\mathrm{m} M$ & Liquid L & 0.208 & -4.05 & 0.41 & 3.03 & 26.0 \\
\hline & $\mathrm{mmol}$ & Liquid L & 26.6 & $-1,100.2$ & 0.67 & 223.6 & 24.5 \\
\hline \multirow[t]{3}{*}{ Total AA } & $\mathrm{m} M$ & mmol & 0.0103 & 1.07 & 0.82 & 0.65 & 13.2 \\
\hline & $\mathrm{m} M$ & Liquid L & 0.015 & 3.79 & 0.01 & 1.52 & 30.8 \\
\hline & $\mathrm{mmol}$ & Liquid L & 5.67 & -53.9 & 0.27 & 115.4 & 30.7 \\
\hline
\end{tabular}

${ }^{1} \mathrm{OA}=$ organic acids (total $\mathrm{OA}=$ the sum of acetate, propionate, butyrate, valerate, and lactate; $\mathrm{C}$ in $\mathrm{OA}=$ carbon in the summed $\mathrm{OA}$ ); $\mathrm{BCVFA}$ = branched-chain VFA.

${ }^{2}$ Liquid $\mathrm{L}=$ ruminal digesta liquid liters measured $2 \mathrm{~h}$ postfeeding; $1 \mathrm{~kg}$ (as measured) was assumed to equal $1 \mathrm{~L}$.

${ }^{3}$ Root mean square error.

as strongly correlated with organic acids $\left(\mathrm{R}^{2}=0.66\right)$ as they were other analytes. Daily DMI was not correlated with the 2-h postfeeding liquid volume $(\mathrm{r}=0.26 ; P=$ $0.22)$, organic acid concentration $(\mathrm{r}=-0.08 ; P=0.72)$, or organic acid pool size $(\mathrm{r}=0.15 ; P=0.48)$. The relationships for $\mathrm{C}$ in organic acids showed a similar pattern to that of total organic acids.

The relationships among ruminal liquid volume, pool size, and concentration for organic acids may be explained by the homeostatic mechanism that modulates osmolality (concentration of solutes) in the rumen relative to that in blood. Solutes in the rumen include soluble minerals, organic acids, ammonia, AA, and soluble carbohydrates, with VFA representing 30 to $40 \%$ of the total (Warner and Stacy, 1965; Girard et al., 2009). Water passage into or absorption from the rumen is primarily driven by the osmotic gradient between the rumen and the blood (Dobson, 1984). If rumen fluid is relatively hypotonic to blood, water is absorbed out of the rumen, or if rumen fluid is relatively hypertonic, water is absorbed across the epithelium and into the rumen (Tabaru et al., 1990). Entry of water into the rumen has the effect of diluting ruminal concentrations of solutes.

In the present study, the linear relationship of moles of organic acid to volume of liquid in the rumen fits well with the concept that water entry into the rumen changes with ruminal solute content. It also explains why a treatment that affects organic acid production or amount of solutes in the rumen may also affect ruminal liquid amount. The poorer relationship of organic acid concentration to ruminal liquid or to pool size likely reflects the effect of water influx or absorption as it compresses the range of organic acid concentrations. Variability of the concentration data was also less than that of pool size. Although organic acid concentrations and pool sizes measured in the present study have maxima that are approximately twice the smallest value measured (94 to $184 \mathrm{mM}$ and 6.0 to $15.8 \mathrm{~mol}$ ) the variation in the data are less for concentration $(\mathrm{CV}$ percentage $=13 \%$ ) than for pool size (CV percentage $=24 \%$ ). It is not surprising for ruminal organic acid concentrations to show less variation than pool sizes if a homeostatic mechanism is regulating them.

The relatively poor correlation between ruminal concentration and pool size data for organic acids compared with other analytes is problematic. Historically, ruminal concentrations were measured to assess the effect of treatments on ruminal fermentation, with the implicit intent of evaluating the effect on nutrient supply to the animal. Researchers have pointed out that ruminal VFA concentrations are the result of production and absorption and so do not necessarily reflect fermentation rates (Dijkstra et al., 1993), and that a lack of relationship between ruminally digested $\mathrm{OM}$ and organic acid concentrations may be related to absorption and passage (Oba and Allen, 2003a). The differing ruminal liquid volumes also affect our ability to accurately interpret the meaning of ruminal concentrations in terms of treatment effects, because the concentrations are not on an equivalent basis necessary for comparisons. Differences among and within research 
studies in liquid volume could explain variation in ruminal concentration responses across studies, including why some studies reported effects of protein on ruminal organic acid concentrations (Herrera-Saldana and $\mathrm{Hu}-$ ber, 1989; Aldrich, et al., 1993), whereas such differences were noted primarily in the pool size comparisons in the present study. In light of the potential effect of differing amounts of ruminal liquid, especially if they are affected by treatment, ruminal organic acid concentrations alone may have little use for accurately describing effects of treatments. The utility of VFA molar percentages and of $\mathrm{pH}$ as a descriptor of rumen environment are not affected. Evaluation and integration of ruminal concentration, liquid volume, liquid flow from the rumen, and if possible, ruminal absorption, would more completely describe the effects of treatment on ruminal fermentation of diets and on organic acid supply to the animal.

The degree to which ruminal liquid volumes vary in dairy cattle is not well detailed in the literature. Large differences in rumen liquid volume between dietary treatments have been reported. In a study in which all-forage diets were offered, lactating cows had approximately $10 \%$ greater quantities of ruminal liquid phase when offered alfalfa silage or alfalfa hay than with corn silage, although the amounts of solid phase did not differ (Hristov and Broderick, 1996). In that study, free water intakes of cows offered alfalfa silage or hay were $60 \%$ greater than for cows offered corn silage, whereas average DMI was only $13 \%$ greater with the alfalfa feeds. The alfalfa hay and corn silage diets offered in that study contained 44.9, 47.9, and $39.2 \%$ $\mathrm{NDF}$ and $20.9,18.3$, and $14.2 \% \mathrm{CP}$, respectively. Liquid passage rates did not differ among treatments. However, when similar passage rates are applied to differing sizes of ruminal liquid pools, daily flows of liquid from the rumen may differ.

Concentrations From 5-h Time-Course Sampling. In contrast to the pool size data, ruminal concentrations measured over $5 \mathrm{~h}$ showed less striking effects of treatment (Table 8; Supplemental Table S1, available online at http://dx.doi.org/10.3168/jds.20125663). Average ruminal $\mathrm{pH}$ of measures taken over $5 \mathrm{~h}$ did not differ by treatment $(P>0.21$; Table 9$)$. Ruminal $\mathrm{pH}$ did exhibit a time $\times$ RDP effect, with $+\mathrm{RDP}$ giving a higher $\mathrm{pH}$ than $-\mathrm{RDP}$ in the later sampling hours $(P$ $=0.04 ;$ Figure 1a). Treatment $\times$ time effects for starch source $(P=0.15)$ and the interaction of treatments $(P$ $=0.75)$ were not detected.

Average concentrations of total organic acids exclusive of BCVFA tended to be affected by the interaction of starch source and RDP $(P=0.14$; Table 9$)$. Values were lower for cows consuming $\mathrm{DG}+\mathrm{RDP}$ than with DG-RDP and, although the difference was smaller, was greater with $\mathrm{HM}+\mathrm{RDP}$ than with $\mathrm{HM}-\mathrm{RDP}$ diets. Concentrations of both organic acids (Figure 1b) and C from organic acids $(P<0.01$ for both) were influenced by the interaction of time and RDP treatment, with

Table 9. Ruminal measures of $\mathrm{pH}$, organic acids, and protein breakdown products (values are LSM of repeated samplings over 5 h)

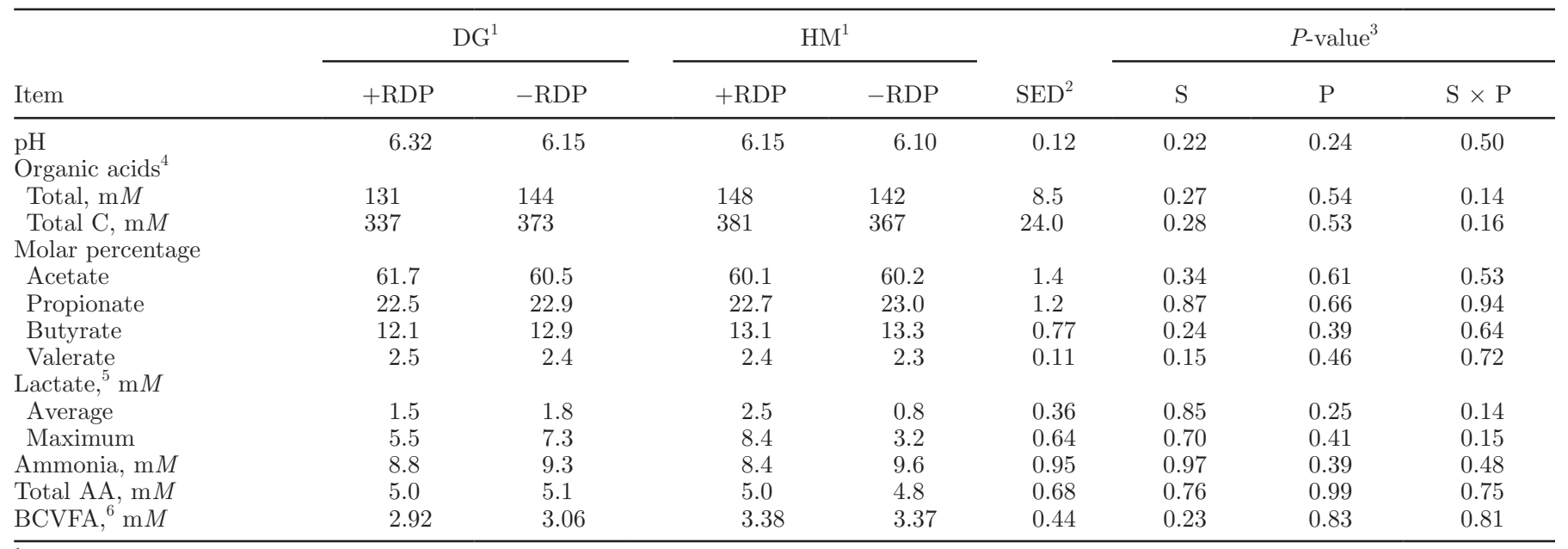

${ }^{1}$ Experimental treatments: $\mathrm{DG}=$ dry ground corn, $\mathrm{HM}=$ high-moisture corn, $+\mathrm{RDP}=$ more RDP, and $-\mathrm{RDP}=$ less $\mathrm{RDP}$.

${ }^{2}$ Standard error of the difference.

${ }^{3}$ Effects: $\mathrm{S}=$ starch source, $\mathrm{P}=\mathrm{RDP}$ treatment, and $\mathrm{S} \times \mathrm{P}=$ interaction.

${ }^{4}$ Total organic acids $=$ sum of acetate, propionate, butyrate, valerate, and lactate. Total organic acid $\mathrm{C}=$ total carbon in the summed organic acids.

${ }^{5}$ Statistical analyses were performed on the average and maximum lactate concentrations detected over $5 \mathrm{~h}$ of sampling; the SED of lactate concentrations are the square root-transformed results.

${ }^{6}$ Branched-chain VFA. 

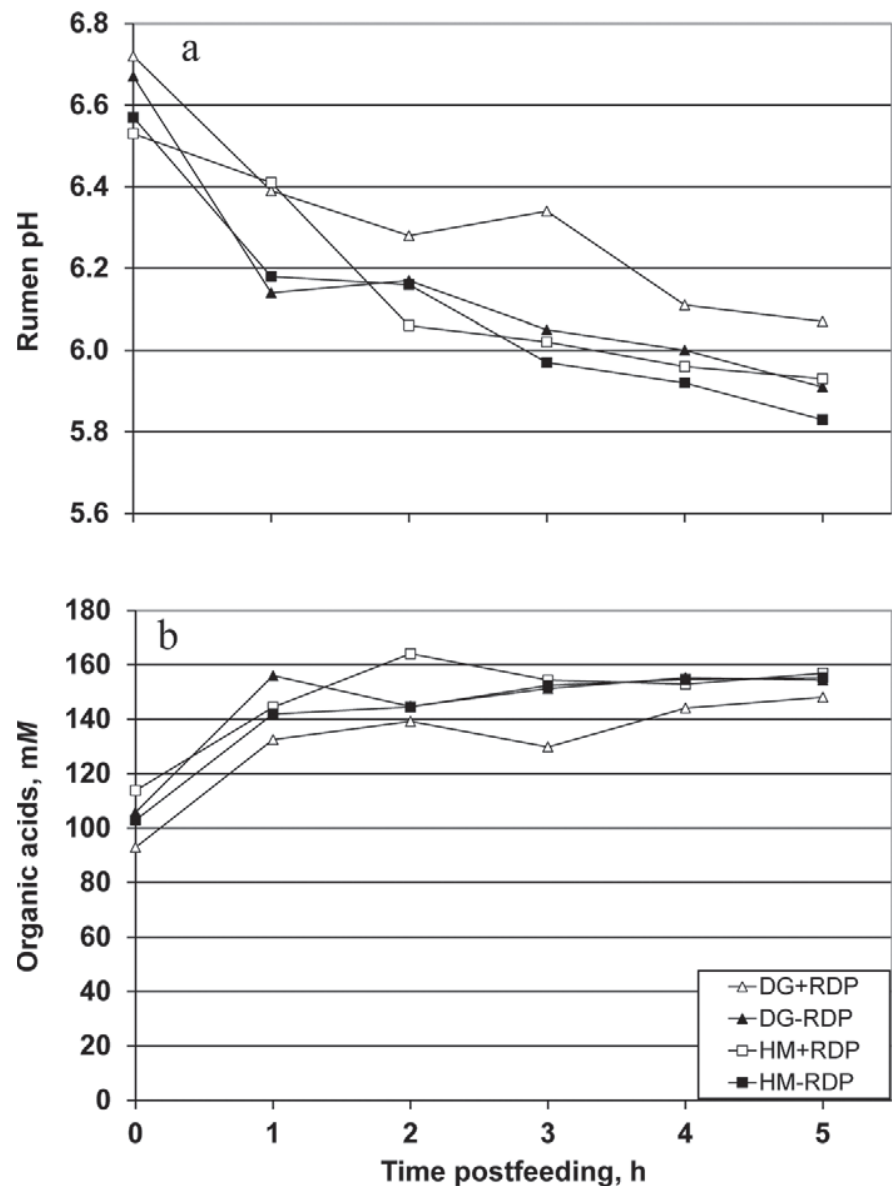

Figure 1. Ruminal pH (a) and organic acid concentrations (b) measured through $5 \mathrm{~h}$ postfeeding. Values are LSM of data. Organic acids are the sum of acetate, propionate, butyrate, valerate, and lactate. Treatments were starch source: $\mathrm{DG}=$ dry ground corn and HM $=$ high-moisture corn, and dietary protein degradability: $+\mathrm{RDP}=$ added protein from soybean meal (greater degradability) and - RDP $=$ heat-treated expeller soybean product partially substituted for soybean meal (lower degradability). The $\mathrm{pH}$ was influenced by RDP $\times$ time $[P=0.04 ; \mathrm{SE}$ of the difference $(\mathrm{SED})=0.08]$. For organic acid concentrations, an effect of RDP $\times$ time $(P<0.01 ;$ SED $=5.7)$ and a tendency for starch source $\times$ time $(P=0.06$; SED $=5.7)$ were detected.

$\mathrm{C}$ in organic acids closely following the same pattern over time as the organic acids (data not shown). At $1 \mathrm{~h}$ postfeeding, total organic acid values for -RDP increased above those of $+\mathrm{RDP}$, the treatments became more similar at $2 \mathrm{~h}$, and then - RDP increased above $+\mathrm{RDP}$ at 3 and $4 \mathrm{~h}$. The interaction of time and starch source tended to have an effect on total organic acids $(P=0.06 ; P=0.08$ for $\mathrm{C}$ in organic acids), with HM increasing above DG at 2 and $3 \mathrm{~h}$ postfeeding. Significant interactions of time, starch source, and RDP were not detected $(P=0.58$ and 0.66 for organic acids and $\mathrm{C}$ in organic acids, respectively). In contrast to these results, a tendency for greater ruminal concentrations of organic acids when feeding diets containing relatively more RDP was reported by Herrera-Saldana and Huber (1989) and Aldrich et al. (1993).

Acetate molar percentages were influenced by the interaction of RDP and time from prefeeding to $2 \mathrm{~h}$ postfeeding $(P=0.04$; Figure $2 \mathrm{a})$. Acetate molar percentages were more similar at 0 - and 2 -h samplings, but diverged at $1 \mathrm{~h}$, with greater values for cows consuming $+\mathrm{RDP}$ diets than for those on $-\mathrm{RDP}$. The responses in the early hours postfeeding agree with a report that molar percentages of acetate decreased when dietary protein degradability was reduced in diets containing similar concentrations of CP (Higginbotham et al., 1989). Butyrate molar percentages were influenced by time and treatment interactions (3-way interaction, $P$ $=0.11$; Figure 2c). Prior to feeding, butyrate molar percentages for all treatments were numerically similar. Cow responses diverged postfeeding, with animals given $\mathrm{HM}-\mathrm{RDP}$ having the greatest butyrate molar percentage, and those consuming DG+RDP the lowest. No treatment or treatment $\times$ time effects were detected for molar percentages of propionate $(P>0.66$; Figure $2 \mathrm{~b}$; Table 9$)$ or valerate $(P \geq 0.15$; Table 9$)$. No effects of treatment without time interaction were noted (Table 9).

Average ruminal lactate concentrations were affected by the interaction of starch source and RDP treatment $(P=0.14$; Table 9$)$, tending to be greater for cows receiving HM+RDP compared with HM-RDP, and more similar between DG+RDP and DG-RDP. Maximal lactate concentrations were unaffected by treatment $(P \geq 0.15)$. Unlike acetate, propionate, and butyrate, ruminal lactate is subject to relatively rapid production and metabolism by rumen microbes (Russell and Wallace, 1988). Of 144 hourly data points in the present study, 41 were $>1 \mathrm{~m} M$, with a maximum detected value of $28 \mathrm{~m} M$. In 1 cow, no hourly measure $>1$ $\mathrm{m} M$ was detected. For the second sampling hour across all periods, +RDP showed lactate concentrations less than and greater than $1 \mathrm{~m} M$, whereas all $-\mathrm{RDP}$ values were $<1 \mathrm{~m} M$. This pattern of data made it challenging to analyze statistically. We were unable to transform the entire data set to achieve a normal distribution. However, square root transformation achieved normal distributions for average and maximal concentration data sets.

Ruminal ammonia concentrations tended to be affected by RDP $\times$ time $(P=0.14$; Table 9 ; Figure $3 a)$, but with results the reverse of what would be expected. Ruminal ammonia concentrations were numerically similar before feeding, were greater with - RDP than with + RDP at $1 \mathrm{~h}$ postfeeding, and then varied across later hours, but with cows consuming HM-RDP having the highest values and those receiving $\mathrm{DG}+\mathrm{RDP}$ having lower values. Increases in dietary RDP would be 

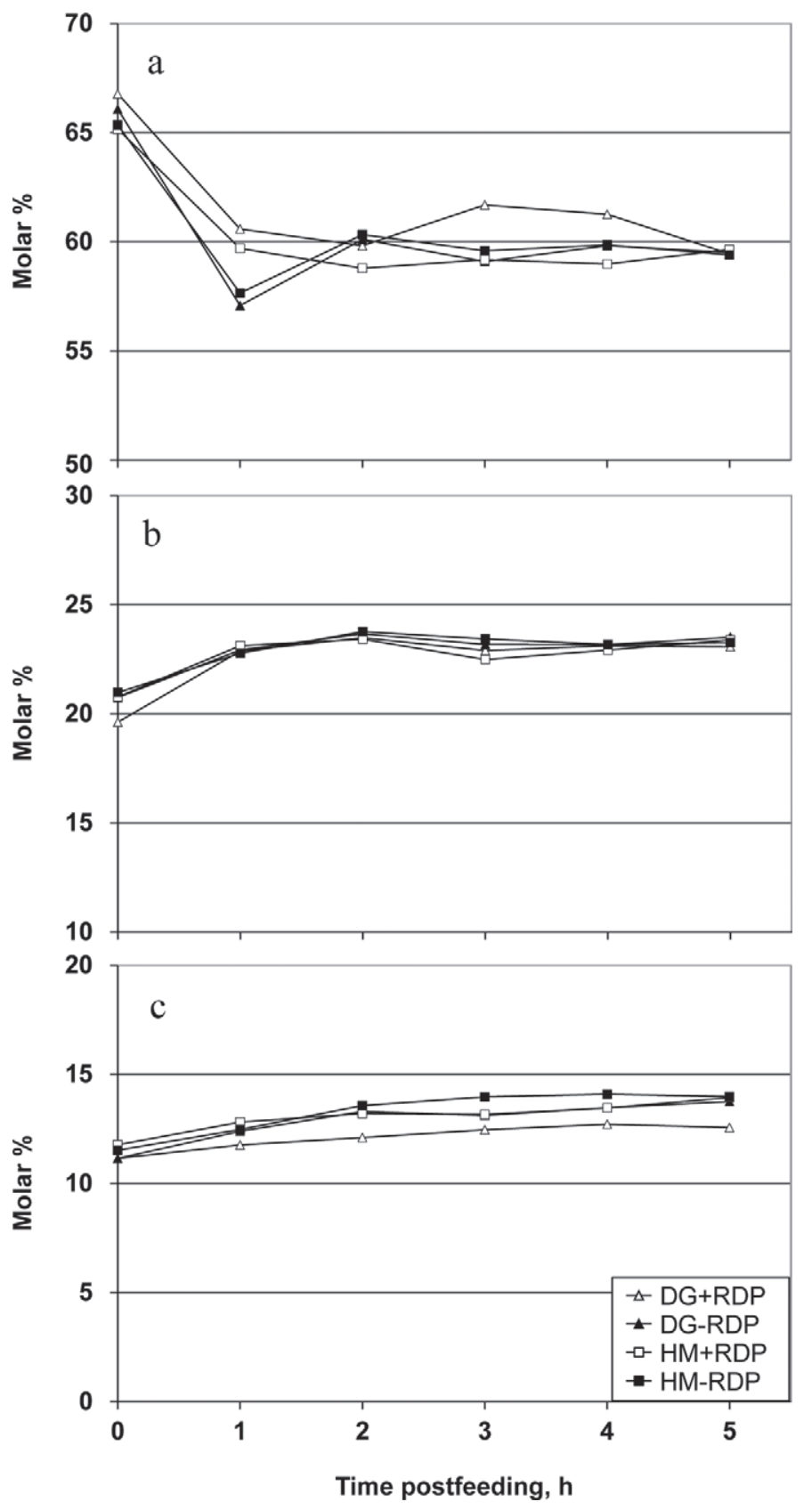

Figure 2. Molar proportions of ruminal acetate (a), propionate (b), and butyrate (c) measured through $5 \mathrm{~h}$ postfeeding. Values are LSM of data. Treatments were starch source: DG $=$ dry ground corn and $\mathrm{HM}=$ high-moisture corn, and dietary protein degradability: $+\mathrm{RDP}=$ added protein from soybean meal (greater degradability) and $-\mathrm{RDP}=$ heat-treated expeller soybean product partially substituted for soybean meal (lower degradability). A tendency for an effect of starch source $\times$ RDP $\times$ time $[P=0.11$; SE of the difference (SED) $=0.8 \%]$ was detected for butyrate. No other time $\times$ treatment effects across all hours were detected.

expected to increase ruminal ammonia, given equivalent ruminal $\mathrm{pH}$ and fermentability of starch sources. Total ruminal AA concentrations tended to show an effect of $\operatorname{RDP} \times$ time $(P=0.10$; Figure $3 \mathrm{~b})$, with -
$\mathrm{RDP}$ concentrations rising above $+\mathrm{RDP}$ at $1 \mathrm{~h}$ and then decreasing below $+\mathrm{RDP}$ at $2 \mathrm{~h}$ postfeeding. No other time $\times$ treatment effects were detected for total AA concentrations $(P>0.22)$, nor were direct effects of treatments or their interaction $(P>0.74$; Table 9$)$.

Average ruminal BCVFA concentrations were not affected by treatment $(P>0.22$; Table 9$)$, but tended to be influenced by the interaction of starch source by RDP by time postfeeding $(P=0.06$; Figure $3 \mathrm{c})$. At 3 and $4 \mathrm{~h}$ postfeeding, values for the RDP treatments within DG were similar, whereas those for HM showed $-\mathrm{RDP}$ greater than $+\mathrm{RDP}$. Overall, $-\mathrm{RDP}$ values were numerically greater than $+\mathrm{RDP}$ values within starch source. These results do not appear to be consistent with the concept that increases in ruminal degradability of AA sources have potential to give greater BCVFA concentrations, unless utilization of AA and BCVFA are altered or the treatments differ in ruminal dilution.

The issue of the effect of varying ruminal liquid amount on concentrations casts doubt on our ability to definitively interpret the quantitative effects of treatment for the time-course concentration data, except for changes in $\mathrm{pH}$ and organic acid molar percentages. That kilograms of digesta liquid were greater with +RDP compared with -RDP both pre- and postfeeding suggests that differences in the amount of ruminal liquid between these treatments would be maintained over the rest of the day, although the actual amounts would likely vary. Dilution of fermentation products into different volumes of liquid can give differing or similar concentrations, irrespective of the yield of fermentation product from DM. Depression in concentrations of ammonia, total AA, and BCVFA as liquid volumes increase could explain why provision of increased amounts of RDP gave lower concentrations of protein degradation products. Further interpretation of the time-course concentration data are hindered by lack of information on the corresponding ruminal liquid volumes.

\section{Potential Mechanism for Protein Effects}

The effects of RDP on ruminal organic acid and lactate pool sizes may be related to an indirect effect of $\mathrm{RDP}$ on cell energy demand as mediated through microbial storage of glycogen. A proposed scheme describing factors and effects is shown in Figure 4. Glycogen is a microbial storage carbohydrate that contains glucose bound with $\alpha-1,4$ and $\alpha-1,6$ linkages as in starch. $\mathrm{Ru}-$ minal protozoa and solid- and liquid-associated bacteria can convert a variety of carbohydrate substrates to glycogen (Thomas, 1960; Gaudet et al., 1992). Synthesis of glycogen comes at a cost of 1 ATP per hexose incorporated (Stouthamer, 1973), which is one-quarter 

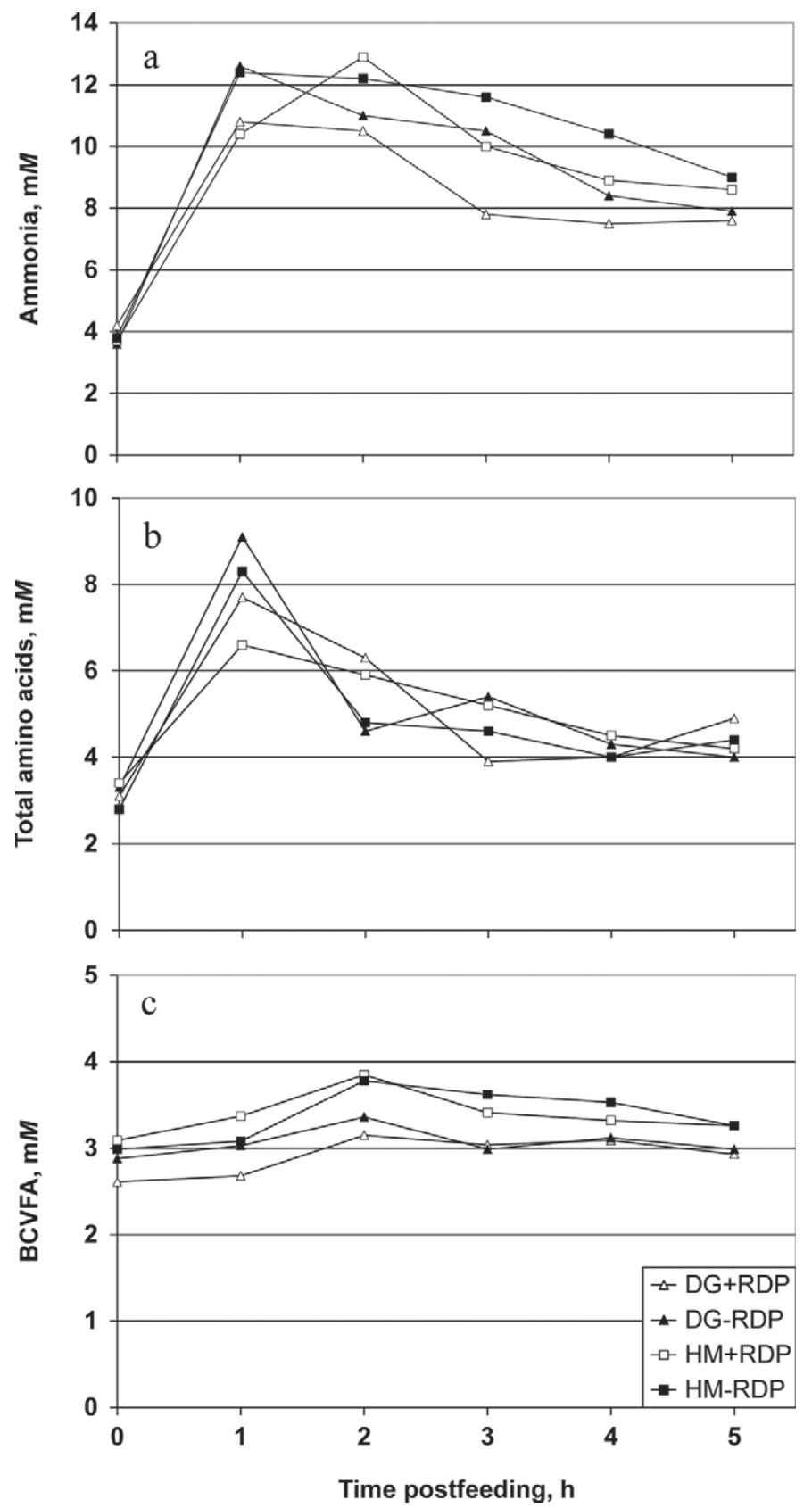

Figure 3. Ruminal concentrations of protein breakdown products ammonia (a), total AA (b), and branched-chain VFA (BCVFA; c) measured through $5 \mathrm{~h}$ postfeeding. Values are LSM of data. Treatments were starch source: DG = dry ground corn and $\mathrm{HM}=$ high-moisture corn, and dietary protein degradability: $+\mathrm{RDP}=$ added protein from soybean meal (greater degradability) and $-\mathrm{RDP}=$ heat-treated expeller soybean product partially substituted for soybean meal (lower degradability). Tendencies for effects of RDP $\times$ time on total AA $[P=$ 0.10; $\mathrm{SE}$ of the difference $(\mathrm{SED})=0.81]$ and on ammonia $(P=0.14$ SED $=1.21)$, and of starch source $\times$ RDP $\times$ time on BCVFA $(P=$ $0.06 ; \mathrm{SED}=0.41)$ were detected. No other time $\times$ treatment effects detected. to one-half of the total ATP that bacteria may derive per hexose fermented (Russell and Wallace, 1988).

Microbial glycogen formation is enhanced when uptake of carbohydrate is in excess of the capacity to process the hexoses through glycolysis or to utilize the ATP that would be generated. Glycogen storage is increased by increases in the amount of rapidly assimilated carbohydrate substrate (Prins and Van Hoven, 1977) and the amount of intracellular glycolytic intermediates (Ball and Morell, 2003). It decreases with increases in AMP, ADP, and orthophosphate, which signal decreased energy status of the cell (Ball and Morell, 2003) and increased cellular demand for ATP. Under conditions where energy is not limiting, glycogen production utilizes ATP, but the process would be less favored if competing demands existed for ATP. Thus, glycogen synthesis is responsive to factors that affect energy status of the cell. Fundamentally, if cells have immediate need for energy, hexose is fermented and not stored as glycogen; if they do not, the storage of glycogen allows them to sequester substrate internally for future use. Glycogen storage thus defers fermentation of carbohydrate to a later time and possibly at a reduced rate compared with that of the original substrate (glycogen fermentation rates: 23\%/h; Van Kessel and Russell, 1997; 15 to $17 \% / \mathrm{h}$, calculated from data of Prins and Van Hoven, 1977).

Dietary protein also has been shown to affect glycogen storage in bacterial cells. Increases in dietary protein concentration decreased the proportion of glycogen per unit of isolated dry ruminal bacterial cells (McAllan and Smith, 1974). The protein effect is a function of RDP rather than of total protein (Williams et al., 1973).

Degradable protein supply may affect glycogen storage and lactate production, as noted in the present study, by altering the energy demands of microbial cells through influence on cell growth. It has been shown that increases in the supply of AA and peptides linearly increase the yield of micrograms of RNA (a proxy for cell growth) per amount of carbohydrate substrate at all levels of carbohydrate provided (Argyle and Baldwin, 1989). This increase in efficiency of microbial growth has also been shown in vivo with ruminal casein supplementation (Köster et al., 1996). It is possible that by providing a limiting nutrient such as N, AA, or peptides, RDP increases microbial cell growth and associated ATP demands for synthesis of macromolecules. Such a change in ATP demand would provide signals (increased ADP and orthophosphate) to decrease glycogen synthesis, and increase the flow of hexoses through glycolysis, which would also increase lactate production (Counotte and Prins, 1981). It seems likely that this effect of RDP would be noted with a rapidly 


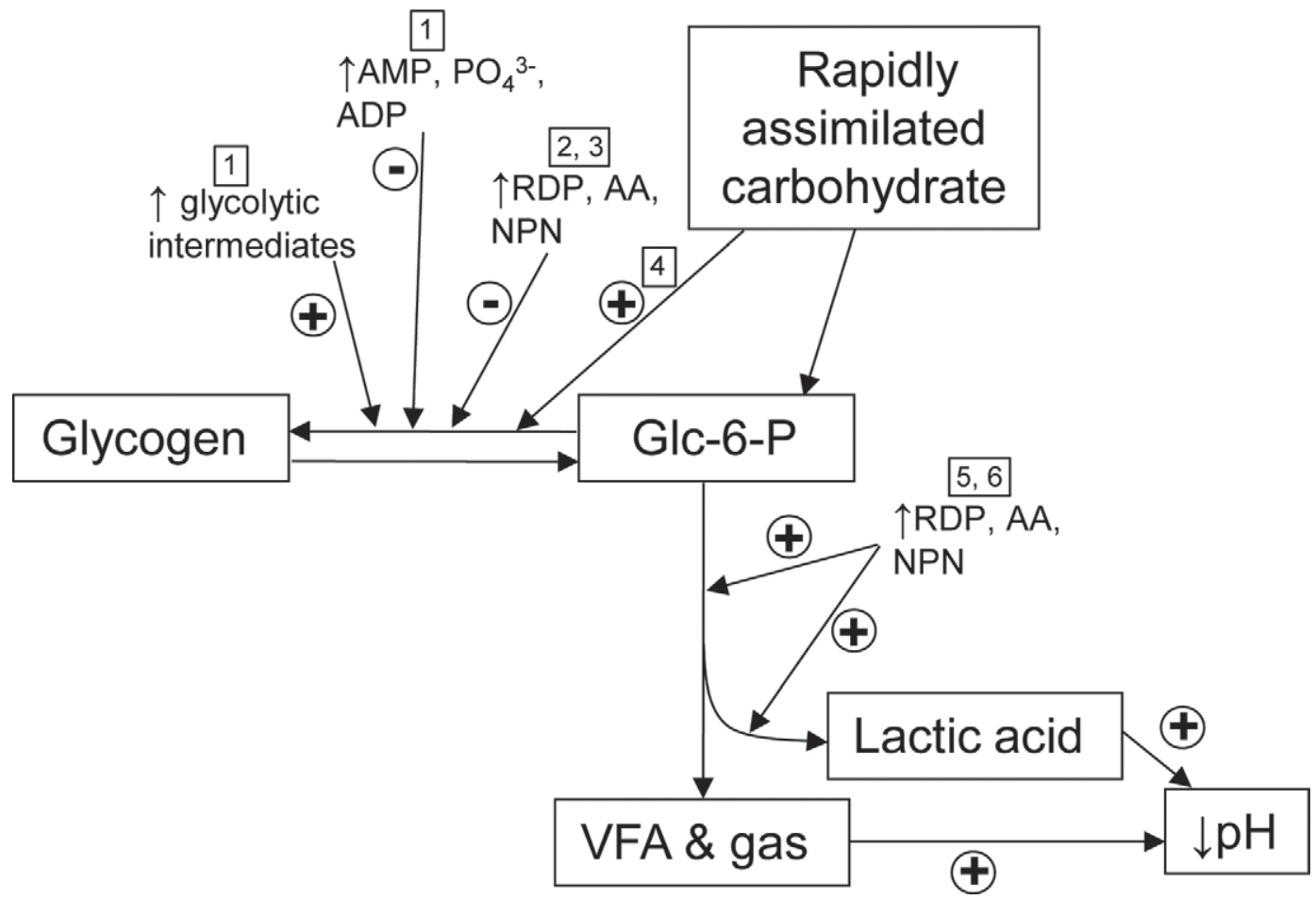

Figure 4. Proposed scheme describing factors affecting carbohydrate fermentation in the rumen. Solid lines indicate the direction of reactions from substrate to product. Dashed lines indicate effects on production of products, with "+" indicating an effect that increases and "-" indicating an effect that decreases product formation. The effect of RDP, AA, and NPN on glycolysis is assumed based on the negative effect of these sources of $\mathrm{N}$ on glycogen synthesis and positive effect on lactic acid production. $\mathrm{PO}_{4}{ }^{3-}=$ orthophosphate; Glc-6-P $=$ glucose-6-phosphate. The upward arrows indicate increased amounts and the downward arrow indicates a decreased value. Numbers in boxes are citations for effects: $1=$ Ball and Morell (2003), $2=$ Williams et al. (1973), $3=$ McAllan and Smith (1974), $4=$ Prins and Van Hoven (1977), $5=$ Counotte and Prins (1981), and $6=$ Malestein et al. (1984).

assimilated, but not with a more slowly assimilated carbohydrate substrate. The latter would be less likely to trigger the conditions that increase glycogen storage, unless required nutrients were limiting relative to the rate of carbohydrate assimilation by microbes.

Describing the effect of RDP in terms of microbial ATP usage also gives a context for the effect of protein supplementation on energy spilling (Figure 5). Provision of AA increased the growth efficiency of Streptococcus bovis and decreased the specific rate of heat production (energy spilling), although no change was observed in glucose consumption by the cultures (Russell, 1993). Hypothetically, AA supplementation could reduce energy spilling by providing an alternative way to dissipate ATP via cell growth. Both energy spilling and glycogen synthesis may be viewed as alternative routes by which bacteria cope with captured substrate that is in excess of the energy needs of the cell. Either case entails ATP costs, but denies substrate to other competing microbes.

In the present study, in vivo production of microbial glycogen was not verified because it is not feasible to do so with animals offered diets containing starch. Glycogen in microbes (Hall, 2011) and resistant starch in feeds (McCleary et al., 2002) are both measured by treatment of samples with alkali and use of an enzymatic starch assay. With the inability to adequately separate microbes from feed in the digesta, resistant starch from feed is indistinguishable from microbial glycogen. Thus, an accurate glycogen value is not obtained unless no starch is present in the diet or contaminates the sample. For the same reason, ruminal starch digestibility is a measure of apparent digestibility; it reflects the disappearance of dietary starch, underestimated by the net amount of glycogen produced from all carbohydrates.

\section{CONCLUSIONS}

Supply of RDP influenced ruminal measures such as organic acid and lactate pool sizes that are normally considered to be affected primarily by carbohydrate fermentation. Few interactions of starch source and protein degradability were detected. A proposed mechanism describing the effects of RDP via interrelationships of glycogen storage and hexose flux through glycolysis in response to bacterial energy demands appears to be consistent with the ruminal results from this and 


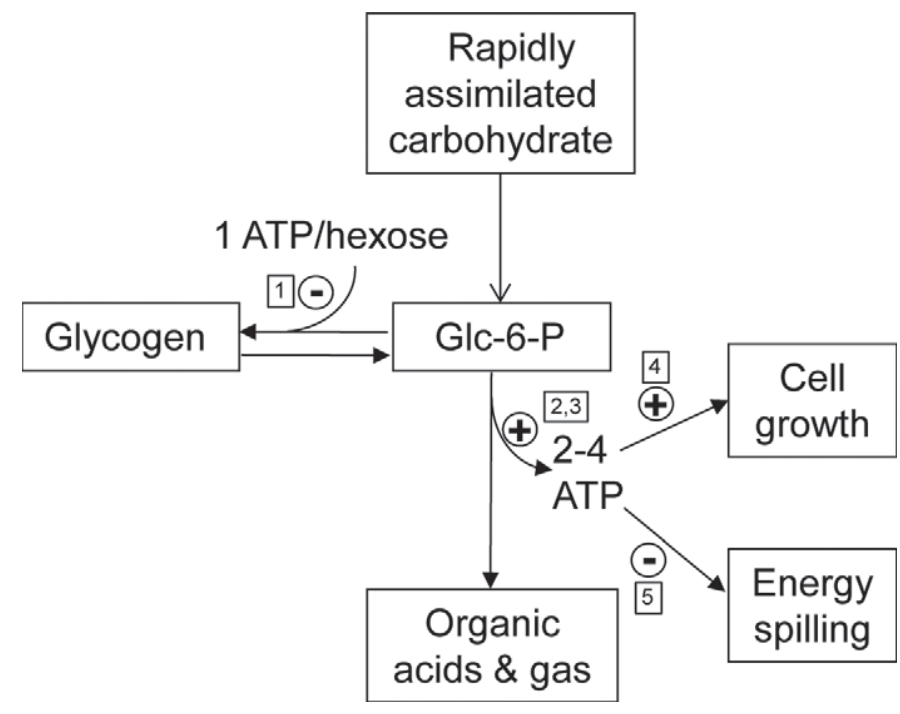

Figure 5. Proposed scheme for effects of degradable protein or AA and peptide supplementation on ATP usage related to glycogen synthesis, flux of hexose through glycolysis, cell growth, and energy spilling. Nitrogen source effects on processes are designated as "+" (increase) or "-" (decrease). The effect on glycolysis is assumed based on the negative effect of $\mathrm{N}$ sources on glycogen synthesis and positive effect on lactic acid production. Glc-6-P = glucose-6-phosphate Numbers in boxes are citations for effects: 1 = Stouthamer (1973), 2 $=$ Counotte and Prins (1981), $3=$ Malestein et al. (1984), $4=$ Argyle and Baldwin (1989), and $5=$ Russell (1993).

other in vivo studies. The scheme does not exclude the need to consider effects of $\mathrm{pH}$, passage, and other factors on overall rumen function and output, nor does it determine whether protein-mediated changes will improve nutrient supply to the animal in such a way that production is improved. The proposed mechanism does offer a testable basis for manipulation of dietary factors to modify ruminal fermentation output. The implications of differences in statistical results between ruminal concentrations and pool sizes are problematic for our ability to interpret responses to treatments. Varying ruminal liquid volumes compromise our ability to accurately interpret ruminal concentrations as metrics describing or unambiguously associated with ruminal fermentation, ruminal OM digestion, and supply of nutrients to the cow. This appears to be a particular issue for organic acids, possibly because they represent the largest pool of solute derived from fermentation of OM. A more detailed assessment is needed regarding approaches that will improve our ability to evaluate and interpret treatment effects on ruminal fermentation product formation.

\section{REFERENCES}

Aldrich, J. M., L. D. Muller, G. A. Varga, and L. C. Griel Jr. 1993. Nonstructural carbohydrate and protein effects on rumen fermentation, nutrient flow, and performance of dairy cows. J. Dairy Sci. 76:1091-1105.
AOAC (Association of Official Analytical Chemists). 1990. Official Methods of Analysis. 15th ed. AOAC, Arlington, VA.

Argyle, J. L., and R. L. Baldwin. 1989. Effects of amino acids and peptides on rumen microbial growth yields. J. Dairy Sci. 72:20172027.

Ball, S. G., and M. K. Morell. 2003. From bacterial glycogen to starch: Understanding the biogenesis of the plant starch granule. Annu. Rev. Plant Biol. 54:207-233.

Boone, D. R., G. M. Garrity, and D. Hendricks. 2010. Page 99 in Bergey's Manual of Systematic Bacteriology, Vol. 4. Williams and Wilkins.

Broderick, G. A., P. Udén, M. L. Murphy, and A. Lapins. 2004. Sources of variation in rates of in vitro ruminal protein degradation. J. Dairy Sci. 87:1345-1359.

Carruthers, V. R., and P. G. Neil. 1997. Milk production and ruminal metabolites from cows offered two pasture diets supplemented with non-structural carbohydrate. N. Z. J. Agric. Res. 40:513-521.

Colombini, S., G. A. Broderick, and M. K. Slayton. 2011. Effect of quantifying peptide release on ruminal protein degradation determined using the inhibitor in vitro system. J. Dairy Sci. 94:19671977.

Counotte, G. H. M., and R. A. Prins. 1981. Regulation of lactate metabolism in the rumen. Vet. Res. Commun. 5:101-115.

Crawford, R. J., Jr., W. H. Hoover, C. J. Sniffen, and B. A. Crooker. 1978. Degradation of feedstuff nitrogen in the rumen vs nitrogen solubility in three solvents. J. Anim. Sci. 46:1768-1775.

Dado, R. G., and M. S. Allen. 1994. Variation in and relationships among feeding, chewing, and drinking variables for lactating dairy cows. J. Dairy Sci. 77:132-144.

Dijkstra, J., H. Boer, J. Van-Bruchem, M. Bruining, and S. Tamminga. 1993. Absorption of volatile fatty acids from the rumen of lactating dairy cows as influenced by volatile fatty acid concentration, $\mathrm{pH}$ and rumen liquid volume. Br. J. Nutr. 69:385-396.

Dobson, A. 1984. Blood flow and absorption from the rumen. Q. J. Exp. Physiol. 69:599-606.

El-Shazly, K. 1952. Degradation of protein in the rumen of the sheep. 1. Some volatile fatty acids, including branched-chain isomers, found in vivo. Biochem. J. 51:640-647.

Fernando, S. C., H. T. Purvis II, F. Z. Najar, L. O. Sukharnikov, C. R. Krehbiel, T. G. Nagaraja, B. A. Roe, and U. DeSilva. 2010. Rumen microbial population dynamics during adaptation to highgrain diet. Appl. Environ. Microbiol. 76:7482-7490.

Gaudet, G., E. Forano, G. Dauphin, and A.-M. Delort. 1992. Futile cycling of glycogen in Fibrobacter succinogenes as shown by in situ ${ }^{1} \mathrm{H}-\mathrm{NMR}$ and ${ }^{13} \mathrm{C}-\mathrm{NMR}$ investigation. Eur. J. Biochem. 207:155162.

Girard, C. L., C. Benchaar, J. Chiquette, and A. Desrochers. 2009 Net flux of nutrients across the rumen wall of lactating dairy cows as influenced by dietary supplements of folic acid. J. Dairy Sci. 92:6116-6122.

Griswold, K. E., B. A. White, and R. I. Mackie. 1999. Proteolytic activities of the starch-fermenting ruminal bacterium, Streptococcus bovis. Curr. Microbiol. 39:180-186.

Hall, M. B. 2009. Determination of starch, including maltooligosaccharides, in animal feeds: Comparison of methods and a method recommended for AOAC collaborative study. J. AOAC Int. 92:42-49.

Hall, M. B. 2011. Isotrichid protozoa influence conversion of glucose to glycogen and other microbial products. J. Dairy Sci. 94:45894602.

Hall, M. B., W. H. Hoover, J. P. Jennings, and T. K. Miller Webster. 1999. A method for partitioning neutral detergent-soluble carbohydrates. J. Sci. Food Agric. 79:2079-2086.

Hall, M. B., C. C. Larson, and C. J. Wilcox. 2010. Carbohydrate source and protein degradability alter lactation, ruminal, and blood measures. J. Dairy Sci. 93:311-322.

Heldt, J. S., R. C. Cochran, G. L. Stokka, C. G. Farmer, C. P. Mathis, E. C. Titgemeyer, and T. G. Nagaraja. 1999. Effects of different supplemental sugars and starch fed in combination with degradable intake protein on low-quality forage use by beef steers. J. Anim. Sci. 77:2793-2802. 
Herrera-Saldana, R., and J. T. Huber. 1989. Influence of varying protein and starch degradabilities on performance of lactating cows. J. Dairy Sci. 72:1477-1483.

Higginbotham, G. E., J. T. Huber, M. V. Wallentine, N. P. Johnston, and D. Andrus. 1989. Influence of protein percentage and degradability on performance of lactating cows during moderate temperature. J. Dairy Sci. 72:1818-1823.

Hristov, A. N., and G. A. Broderick. 1996. Synthesis of microbial protein in ruminally cannulated cows fed alfalfa silage, alfalfa hay, or corn silage. J. Dairy Sci. 79:1627-1637.

Johnson, R. R. 1976. Influence of carbohydrate solubility on nonprotein nitrogen utilization in the ruminant. J. Anim. Sci. 43:184191.

Kim, K. H., Y.-G. Oh, J.-J. Choung, and D. G. Chamberlain. 1999. Effects of varying the degree of synchrony of energy and nitrogen release in the rumen on the synthesis of microbial protein in cattle consuming grass silage. J. Sci. Food Agric. 79:833-838.

Köster, H. H., R. C. Cochran, E. C. Titgemeyer, E. S. Vanzant, I. Abdelgadir, and G. St-Jean. 1996. Effect of increasing degradable intake protein on intake and digestion of low-quality, tallgrassprairie forage by beef cows. J. Anim. Sci. 74:2473-2481.

Licitra, G., T. M. Hernandez, and P. J. Van Soest. 1996. Standardization of procedures for nitrogen fractionation of ruminant feeds. Anim. Feed Sci. Technol. 57:347-358.

Malestein, A., A. T. van't Klooster, R. A. Prins, and G. H. M. Counotte. 1984. Concentrate feeding and ruminal fermentation. 3. Influence of concentrate ingredients on $\mathrm{pH}$, on DL-lactic acid concentration in the rumen fluid of dairy cows and on dry matter intake. Neth. J. Agric. Sci. 32:9-21.

McAllan, A. B., and R. H. Smith. 1974. Carbohydrate metabolism in the ruminant: Bacterial carbohydrates formed in the rumen and their contribution to digesta entering the duodenum. Br. J. Nutr. 31:77-88.

McCleary, B. V., M. McNally, and P. Rossiter. 2002. Measurement of resistant starch by enzymatic digestion in starch and selected plant materials: Collaborative study. J. AOAC Int. 85:1103-1111.

Mertens, D. R. 2002. Gravimetric determination of amylase-treated neutral detergent fiber in feeds with refluxing in beakers or crucibles: Collaborative study. J. AOAC Int. 85:1217-1240.

Murphy, M. R. 1982. Analyzing and presenting pH data. J. Dairy Sci. 65:161-163.

Murphy, M. R. 1992. Water metabolism of dairy cattle. J. Dairy Sci. 75:326-333.

NRC. 2001. Nutrient Requirements of Dairy Cattle. 7th rev. ed. Natl. Acad. Sci., Washington, DC.

Oba, M., and M. S. Allen. 2003a. Effects of corn grain conservation method on feeding behavior and productivity of lactating dairy cows at two dietary starch concentrations. J. Dairy Sci. 86:174183.

Oba, M., and M. S. Allen. 2003b. Effects of corn grain conservation method on ruminal digestion kinetics for lactating dairy cows at two dietary starch concentrations. J. Dairy Sci. 86:184-194.

Paquay, R., R. De Baere, and A. Lousse. 1970. Statistical research on the fate of water in the adult cow. II. The lactating cow. J. Agric. Sci. 75:251-255.

Pell, A. N., and P. Schofield. 1993. Computerized monitoring of gas production to measure forage digestion in vitro. J. Dairy Sci. 76:1063-1073.
Poppi, D. P., B. W. Norton, D. J. Minson, and R. E. Hendricksen. 1980. The validity of the critical size theory for particles leaving the rumen. J. Agric. Sci. 94:275-280.

Prins, R. A., and W. Van Hoven. 1977. Carbohydrate fermentation by the rumen ciliate Isotricha prostoma. Protistologica (Paris) 13:549-556.

Russell, J. B. 1993. Effect of amino acids on the heat production and growth efficiency of Streptococcus bovis: Balance of anabolic and catabolic rates. Appl. Environ. Microbiol. 59:1747-1751.

Russell, J. B., and R. J. Wallace. 1988. Energy yielding and consuming reactions. Pages 185-215 in The Rumen Microbial Ecosystem. P. N. Hobson, ed. Elsevier, Barking, UK.

SAS Institute. 2010. The SAS System for Windows. Version 9.3. SAS Institute Inc., Cary, NC.

Schofield, P., R. E. Pitt, and A. N. Pell. 1994. Kinetics of fiber digestion from in vitro gas production. J. Anim. Sci. 72:2980-2991.

Steel, R. G. D., and J. H. Torrie. 1960. Principles and Procedures of Statistics. McGraw-Hill Companies, New York, NY.

Stern, M. D., and L. D. Satter. 1984. Evaluation of nitrogen solubility and the Dacron bag technique as methods for estimating protein degradation in the rumen. J. Anim. Sci. 58:714-724.

Stouthamer, A. H. 1973. A theoretical study on the amount of ATP required for synthesis of microbial cell material. Antonie van Leeuwenhoek 39:545-565.

Tabaru, H., K. Ikeda, E. Kadota, Y. Murakami, H. Yamada, N. Sasaki, and A. Takeuchi. 1990. Effects of osmolality on water, electrolytes and VFAs absorption from the isolated ruminoreticulum in the cow. Jpn. J. Vet. Sci. 52:91-96.

Tajima, K., R. I. Aminov, T. Nagamine, H. Matsui, M. Nakamura, and Y. Benno. 2001. Diet-dependent shifts in the bacterial population of the rumen revealed with real-time PCR. Appl. Environ. Microbiol. 67:2766-2774.

Taylor, R. B., J. T. Huber, A. A. Gomez-Alarcon, F. Wiersma, and X. Pang. 1991. Influence of protein degradability and evaporative cooling on performance of dairy cows during hot environmental temperatures. J. Dairy Sci. 74:243-249.

Thomas, G. J. 1960. Metabolism of the soluble carbohydrates of grasses in the rumen of the sheep. J. Agric. Sci. 54:360-372.

Tyrrell, H. F., and J. T. Reid. 1965. Prediction of the energy value of cow's milk. J. Dairy Sci. 48:1215-1223.

Van Kessel, J. S., and J. B. Russell. 1997. The endogenous polysaccharide utilization rate of mixed ruminal bacteria and the effect of energy starvation on ruminal fermentation rates. J. Dairy Sci. 80:2442-2448.

Warner, A. C. I., and B. D. Stacy. 1965. Solutes in the rumen of sheep. Q. J. Exp. Physiol. 50:169-184.

Weimer, P. J., Y. Shi, and C. L. Odt. 1991. A segmented gas/liquid delivery system for continuous culture of microorganisms on solid substrates, and its use for growth of Ruminococcus flavefaciens on cellulose. Appl. Microbiol. Biotechnol. 36:178-183.

Williams, A. P., A. B. McAllan, and R. H. Smith. 1973. Metabolism of casein in the rumen and some effects of formaldehyde treatment. Proc. Nutr. Soc. 32:85A-86A. 